\title{
The Sovereignty Issue in the Public Discussion in the Era of the Polish 3rd May Constitution (1788-1792)
}

\author{
Anna Tarnowska
}

"Nihil sine nobis de nobis"

(nobility parole)

\begin{abstract}
The following study is a result of the first phase of the ReConFort research on the constitutional debate of late eighteenth century in Poland (the so-called First Republic, the Polish-Lithuanian Commonwealth). Several categories of sources, including not only juridical but also political writers' and politicians' private correspondence, were analysed. An analysis of the issue of sovereignty and an interpretation of this concept in journalistic writings and legal acts of that time lead to the conclusion that sovereignty was defined as an external independence and, in particular, as the 'inner freedom'. On the grounds of journalistic writings and the Great Sejm's (the 4-Year Sejm) legal acts the class of nobility remained the sovereign. The articles of the Constitution of the 3rd of May 1791 changed the role of the nobility (possessors), which became henceforth 'the free nation' in a political sense. Its main task was to represent the whole society composed of the nobility, bourgeoisie and peasantry. The adoption of the law on the free royal cities (1791) also provided an opportunity for a more liberal interpretation of the constitution itself. Another matter was a discussion on the position of the monarch related to the problem of his resignation from 'free royal elections', which was the most controversial regulation. The conservatives clearly interpreted these plans of the patriotic fraction as a 'coup d'etat', an attack against the existing freedom and the first step to the introduction of an absolute model of rules.
\end{abstract}

Keywords 3rd of May constitution • Sovereignty • Great Parliament 1788-1792 • Stanisław August Poniatowski $\bullet$ Succession of the throne $\bullet$ Nobility $\bullet$ Nation

\footnotetext{
A. Tarnowska $(\square)$

Faculty of Law and Administration, Nicolaus Copernicus University, Toruń, Poland

e-mail: anna.tarnowska@uni-passau.de; atarn@law.umk.pl
} 


\section{Introductory Remarks}

The ReConFort is an attempt to open a new and very particular perspective. The research conducted under the project essentially focused on the problem of sovereignty. Case studies brought manifold dilemmas. An instance of late eighteenthcentury Poland, the oldest analysed one, could not be embedded in a context of the modern idea of sovereignty. A researcher, in order not to succumb to such temptations which may create artificial structures, is obliged to stick to the precise historical context. The analysis leads to the conclusion that the concept of sovereignty had taken on double meanings within the abovementioned period: 'the external independence and internal freedom', as announced in the preamble to the 3rd of May Constitution. ${ }^{1}$

The first aspect can be associated with the American concept of "independence". The term of "independencja" was implemented at that time into the Polish dictionary by the revolutionaries who took part in the American War of Independence (e.g. Tadeusz Kościuszko). ${ }^{2}$ This point seems to be less interesting with regard to the comprehensive analysis. On the other hand, it is still significant due to the disastrous situation of Poland surrounded by imperial powers and the direct threat associated with it and manifested in the 1st partition of the Polish territory by the Kingdom of Prussia, the Russian and Austrian Empires. This action was finalized by the treaties signed in St. Petersburg on the 5th of August (the 25th of July), 1772 and subsequently approved by the decision of the Polish Parliament (Sejm) forced thereto in 1773. ${ }^{3}$ The interest of the neighbouring powers was to retain the weakness, anarchy, destabilized laws and ineffective executive authorities. The participants of reform move-

\footnotetext{
${ }^{1}$ Text of the Constitution (Polish: Ustawa Rządowa):Volumina Legum, Wydawnictwo Komisyi Prawniczej Akademii Umiejętności w Krakowie, t. IX, Kraków 1889, p. 220-225; in German edition: Willoweit Dietmar, Seif Ulrike. 2003. Europäische Verfassungsgeschichte. Rechtshistorische Texte. München: Verlag C.H.Beck, p. 281-291, in English: a.o. Kasparek Joseph - Obst, 1980. The constitutions of Poland and of the United States. Kinship and genealogy, Miami, Florida: The American Institute of Polish Culture, p. 303-312.

${ }^{2}$ F. Pepłowski for Władysław Konopczyński indicates Stanisław Konarski as the one who first coined this phrase in Latin version. Comp. Pepłowski Franciszek. 1961. Stownictwo i frazeologia polskiej publicystyki okresu oświecenia i romantyzmu, Warszawa: Państwowy Instytut Wydawniczy, p. 44.

${ }^{3}$ The direct cause of action of the partitioners was to be a threat allegedly caused by the "spirit of partiality, supporting the anarchy in Poland", which "makes them fear a complete decomposition of the state, which could damage the interests of the neighbours, adhering to the Republic, undermining good relations between them and igniting a general war. Thus, Austria, Prussia and Russia, having pretences to Poland with regard to the laws as old as true, decided to pursue them, to restore the order within Poland and to ensure this country a political status more in line with the interests of its neighbours”. (“duchem stronniczym, podtrzymującym anarchię w Polsce”, który „każe obawiać się zupełnego rozkładu państwa, co mogłoby zaszkodzić interesom sąsiadów tej rzeczpospolitej, naruszyć dobre stosunki istniejące między nimi i wzniecić ogólną wojnę. Więc Austria, Prusy i Rosja, mając zresztą względem polski pretensję o prawa równie dawne jak słuszne, postanowiły wystąpić z nimi, przywrócić porządek wewnątrz Polski i nadać temu państwu stan polityczny więcej zgodny z interesami jego sąsiadów.”). Cit. after Zielińska Zofia. 1986. Ostatnie lata Pierwszej Rzeczypospolitej, Warszawa: Krajowa Agencja Wydawnicza, p. 18; texts of treaties between Russia and Prussia, Russia and Austria, Prussia an Russia among others in: Recueil des traités, conventions et actes diplomatiques concernant la Pologne 1762-1862, par le Comte d'Angeberg, Paris MDCCCLXII, p. 97-106.
} 
ments of the second half of the eighteenth century, political writers and lawyers particularly emphasized this aspect and treated it as a reason for internal reforms.

The idea of sovereignty in Poland of that time, through the prism of the State's structures, was connected with the concept of freedom, which eventually was theoretically transferred from the level of human beings as its subjects into the structure of the State. This freedom was understood as the good "more valuable than the life and personal happiness" (again the preamble to the 3rd of May Constitution) and it became an argument instrumentally used by debaters throughout the reform period between 1788 and 1792. Thus, sovereignty was also a "thousand-year old" freedom the value that used to preponderate during discussions. ${ }^{4}$ In practise, however, the subject of this freedom, its "guardians" remained solely a political nation, i.e. the noblemen. The catalogue of rights and freedoms dedicated even to the petty nobility, based on the Cardinal Laws adopted in 1791, the 3rd of May Constitution and constitutional bills, ${ }^{6}$ was relatively comprehensive. Incidentally, it should be noted that nobility made up an influential and significant group - up to $8 \%$, or according to other controversial estimates even as much as $10 \%$ of Poland's population. ${ }^{7}$

The debates that took place out of the Polish Parliament, brought forth voices opting for an alliance of the nobility and the bourgeoisie. A tentative expression of these trends was the adoption of the Law on free royal cities in 1791. It was not a very significant step, yet allowed to read the articles of the Constitution in a more liberal perspective. At the same time, the regulations adopted in the analysed period led to the loss of political rights by the poorest group of petty nobility,thus establishing a kind of sui generis property qualification.

Finally, the concept of sovereignty appeared in another context, less emphasised in the following parts of the analysis, however still deserving to be highlighted. Zygmunt Izdebski, a Polish publisher of Jean Bodin's 'Six books on the Republic' found that " a pattern of another sovereignty derives from the tradition of Polish political thought, although it used to be violated by a native anarchy and a foreign tyranny. This is a model of the sovereignty of law."

\footnotetext{
${ }^{4}$ Comp. Grześkowiak-Krwawicz, Anna. 2004. O starożytnej wolności Polaków. Historia wolności polskiej w dyskusjach politycznych i historycznych wieku XVIII. Teki Historyczne - Cahiers d'Histoire - Historical Papers, Londyn: Polskie Towarzystwo Historyczne w Wielkiej Brytanii, XXIII: 34-53, also Grześkowiak Krwawicz, Anna. 2006a. Staropolska koncepcja wolności i jej ewolucja w myśli politycznej XVIII w. Kwartalnik Historyczny, t. CXIII (1): 57-83. The author concluded previous studies in monographic work: Grześkowiak-Krwawicz, Anna. 2006b. Regina libertas. Wolność w polskiej myśli politycznej XVIII wieku, Gdańsk: słowo/obraz terytoria, passim.
}

${ }^{5}$ Krzywoszyński Przemysław. 2007. Suwerenność w myśli szlachty polskiej. In: Nad społeczeństwem staropolskim. T. 1 Kultura- instytucje - gospodarka w XVI - XVIII stuleciu, Łopatecki Karol, Walczak Wojciech (ed.). Białystok: Ośrodek badań Europy ŚrodkowoWschodniej Zakład Historii nowożytnej Instytut Historii Uniwersytet w Białymstoku, p. 16.

${ }^{6}$ Dziadzio Andrzej. 2006. O konstytucji 3 maja 1791 roku na tle koncepcji ustrojowych Oświecenia. Państwo i spoleczeństwo, Rok VI, Nr 4: p. 16 and f.

${ }^{7}$ Comp. however, considerations Rostworowski Emmanuel. 1987. Ilu było w Rzeczypospolitej obywateli szlachty. Kwartalnik Historyczny, 94 (3): 3-58.

8 "Wzór innej suwerenności leży w tradycji polskiej myśli politycznej, choć często bywał gwałcony przez rodzimą anarchię i przez obcą tyranię. Jest to wzór suwerenności prawa”. Idebski Zbigniew. 1958. Bodinus a Polska myśl polityczna. In: Jan Bodin, Andegaweńczyk, Sześć ksiąg o 
Let us provide some introductory remarks. The mentioned foreign intervention caused a change of the political course within the progressive wing of petty nobility. These noblemen were aware of the deep institutional reforms and that was why they split up with the magnates, their so-called 'elder brothers'. They were thus far regarded as the enlightened leadership power that could be trusted. ${ }^{9}$ This phenomenon took the form of a substantive action in the late years of the reign of Stanisław August Poniatowski. He was a king, who from the role of a cockscomb-cosmopolite, Empress Catherine's lover and a Russian ally, turned into the last great reformer of the First Polish Republic. This process was initiated quite timidly in the 1770s with the administrative and educational reforms in order to explode with the legislation passed by the Great Parliament at the end of the 1780s (1788-1792). At the time of the parliamentary debates' inauguration, three political parties could be indicated: primo the Conservatives, secundo the party that supported the king, tertio the liberal party also called the patriotic party, initially distrustful of Stanisław August but soon in a political alliance with the king. Eventually, two political wings emerged: a reactionary and a progressive one, which had been discussing sovereignty from several perspectives. The reformatory efforts were crowned with the enactment of the 3rd of May Constitution and constitution-related acts of law that significantly rebuilt the existing institutional and political regime and - to a much lesser extent the social system. Its reform was planned to be carried out in the following months. Unfortunately, external circumstances, in particular, the armed intervention of Russia, as well as internal causes, e.g. the resistance of the conservative petty nobility in fact led to the actual collapse of the Constitution only a year later after its enactment. The Constitution lost its force, which is why the constitutional practice does not exist. And perhaps for that very reason it became a myth cherished for decades of foreign ruling (1795-1918), a myth of an unfulfilled dream, the dream of liberated Poland.

\section{Planes of Discussion}

There are several planes to which reference should be made while analysing the issue of sovereignty in the final period of the First Republic. A more detailed discussion can refer to the concept of sovereignty itself, the construction of a sovereign as a subject authorized to undertake political actions, in particular, legislative ones, and in this respect, to create laws, including those located highest in the hierarchy of sources of law, cardinal laws, as according to Wielhorski each nation has "an

Rzeczypospolitej, ed. Zbigniew Izdebski, Warszawa: Państwowe Wydawnictwo Naukowe, Bodinus..., p. LXX.

${ }^{9}$ Maciejewski, Janusz. 1977. Pojęcie narodu w myśli republikanów 1767-1775. In: Idee i koncepcje narodu w polskiej myśli politycznej czasów porozbiorowych, Goćkowski Janusz, Walicki Andrzej (ed.), Warszawa: Państwowe Wydaw. Naukowe, p. 22, 33. 
elemental law of its government" ${ }^{10}$ Franciszek Salezy Jezierski further specifies this issue: "The freedom of the nation relies on the government constitution, not on the choice of the person to reign, the power of the King described in reasonable laws, the human rights reserved in their completeness, the legislative authority in the hands of the estates composing the nation, the executive power entrusted with magistrates elected by the estates makes up true freedom." 11

In practice, such a source of decision, a sovereign power could in Poland be found only in the consent of the Parliament, "the uniformity of the three estates, and within them the complete power and authority of the inseparable Republic." 12

The construction of the notion related to the nation and an attempt to define it will be indispensable. Again, it is worth referring to the words of Wielhorski who fairly consistently applies this concept although he himself did not attempt to create a definition: "excluding any other authority, particularly, appointed to watch over the order established in the country, the legislative power and the highest independence are vested only in the Nation itself which is decent and right" ${ }^{13}$ It is necessary to refer to the actual discrepancies between the capacious notion of nation used in the literature and the right to represent its interests reserved only to one estate. It was the concept of the nation now substantially liberated from ethnic connotations (thus e.g. the wording gente Ruthenus, natione Polonus), however, still the Sarmatian myth made up a part of the political concept of the nation, justifying a particular social and political role of lesser nobility by its descent from the ancient tribe of Sarmatians. ${ }^{14}$ Catholicism became another component of the state identity, which brought with it a political result of an exclusion from decision-making of Protestant burghers and Orthodox Christian people as the Russian lesser nobles became

\footnotetext{
10 "pierwiastkowa swego rządu ustawa". Wielhorski Michał, O przywróceniu dawnego rządu według pierwiastkowych Rzeczypospolitej ustaw (About the restoration of elemental laws of the former government of the Republic), n.p. 1775, p. 1. The work of Michal Wielhorski still enjoys the great interest of researchers as they consider him to be a writer who tried to introduce the ideals of the new republican gentry with already enlightened language.

11 "Wolność narodu zasadza się na konstytucyi rządu, nie na wyborze Osoby do panowania, władza Króla rozsądnymi opisana prawami, prawa człowieka zawarowane w swej zupełności, władza prawodawcza złożona w ręku stanów naród składających, władza wykonawcza powierzona magistratom przez stany wybranym, składem jest prawdziwej wolności”. NN [Jezierski Franciszek Salezy], O Bez-Królewiach w Polszcze y Wybieraniu Królów, w Warszawie 1791, p. 8.

${ }^{12}$ Three estates defined as noble deputies in Chamber of Deputies, senators and the King: “jednostajność trzech stanów, a w niej zupełna moc i władza nierozdzielnej Rzeczy Pospolitej”. Leszczyński Stanisław, Głos wolny wolność ubezpieczający, ed. A. Rembowski, Warszawa 2003; comp. Ekes, Janusz. 2001. Trójpodział władzy i zgoda wszystkich. Naczelne zasady "ustroju mieszanego" w staropolskiej refleksji politycznej, Siedlce: Instytut Historii Akademii Podlaskiej, p. 74-81 (80).

${ }^{13}$ wyłączając wszelkie inne władze, do czuwania szczególnie nad porządkiem Kraju ustanowione, samemu tylko Narodowi Moc Prawodawcza y naywyższa Udzielność są przyzwoite y właściwe”. Wielhorski Michał, O przywróceniu..., p. 44-45.

${ }^{14}$ Comp. the reflections of Maciejewski, Janusz. 1977. Pojęcie..., p. 31-32.
} 
converts to Catholicism. ${ }^{15}$ On rare occasions the term "citizens" was used directly in respect of the powers of the sovereign. An instance of its application was recorded in the speech of the priest canon Hajewski in $1790 .^{16}$

Finally, it is necessary to refer to the monarch as the subject of the discussion being analysed. The second half of the eighteenth century brought about a certain turn in the discussion lasting almost for centuries, regarding the position of the king in the specific lesser nobility of the Republic, a turn in the long-standing dispute inter maiestatem ac libertatem. The echoes of the discussion on sovereignty were to take the form of a very real debate on the model of power i.e. the choice between an elective monarchy and hereditary monarchy, perhaps the biggest controversy in the literature of that time. It should also be immediately noted that in the Polish debate there was never any room for the thesis that only the monarch was the sovereign. The assumption that the monarch may be merely the first among equals, the ruler of free people and possibly a separate parliamentary state, a factor in the deliberations, was absolutely approved of. Nonetheless, in practice, his influence was mainly associated with his personal features and his political alliance with the deputies. Wielhorski, already quoted above, refused the king even the role of one of the three states, which was rather commonly assumed by other authors. The position of the king at the threshold of the reform was so weak that, paradoxically, one of the main postulates of the reformers was the strengthening of the monarch's power by implementation of succession to the throne.

\section{Characteristics of Sources}

All the issues mentioned are present both in the parliamentary debate and publicist papers created parallel to the legislative process, in the form of free prints, pamphlets and on the pages of main periodicals. To a lesser extent, according to the findings of the author, the sovereignty debate was reflected in the correspondence of the main protagonists (with the exception of the letters of Ignacy Potocki); however, this problem requires more in-depth queries.

\footnotetext{
${ }^{15}$ Comp. Walicki, Andrzej. 2000. Idea narodu w polskiej myśli oświeceniowej, Warszawa: Polska Akademia Nauk. Instytut Filozofii i Socjologii, p. 22-23. However, the characteristic that the number of deputies of the heretical heterodox nobility participation surpassed even the share of nobility heterodox in total number of gentry. Bardach, Juliusz. 1983. Sejm dawnej Rzeczypospolitej jako najwyższy organ reprezentacyjny. Czasopismo Prawno-Historyczne, XXXV (1): p. 141-142.

${ }^{16}$ Mowa Dowodząca: że przepisy nauk od Prześwietney Komissyi Edukacyi Narodowey dla Szkół Publicznych podane są nie tylko użyteczne Kraiowi ale też potrzebne w szczególności Obywatelom przez Ja. X. Daniela Haiewskiego Kanonika Kijowskiego Nauczyciela Wymowy w Szkołach Akademickich Warszawskich przy rozpoczęciu rocznych nauk dnia 29 września 1790 Roku miana, Biblioteka PAN Kraków, Rps. 177, k. 26: “...w wolnych narodach republikantskich, gdzie bowiem sprawy dobra publicznego są dziełem obywatelów..." ("in free republican nations, where issues for the public good are the work of citizens ...").
} 
A preliminary analysis of parliamentary diaries and journals leads already to the conclusion that the parliamentary debate in the late eighties and early nineties of the eighteenth century, had a specific character - it was an erudite debate, conducted in a baroque rhetoric, full of references to characters and events of the ancient times, classical authors, diplomatic and accommodating, while at the same time, little effective. It is necessary to note that its participants are not professional lawyers but representatives of lesser nobility of varied levels of education; however, their rhetorical skills were always high in price. Speakers were supposed to speak freely, without notes, and provide accurate punchlines to the words expressed by previous speakers. The practice shows, however, that such legislative work stretched beyond measure and fairly easily strayed from the starting point. In the parliamentary discussions, almost theatrical, dramatic techniques were used, with a particular example of this visible on the 3rd of May, 1791, the date of Constitution enactment.

Up to now only fragments of The Parliament Diary ${ }^{17}$ and The Parliament Minutes (Records of Operation $)^{18}$ have been analysed. The publications do not document the entire period of duration of the Great Parliament. A substantial part of parliamentary sessions was recorded only in the form of handwritten minutes (Records of Operations) stored in the Central Archives of Historical Records in Warsaw (Archiwum Główne Akt Dawnych, further cit. as AGAD), whereto were attached e.g. printed speeches of adversaries, which makes the query somewhat difficult. ${ }^{19}$ This category of sources should also include collections of royal speeches, manuscript versions drawn up by royal secretaries and prints from the Printing House of His Royal Majesty. ${ }^{20}$ Difficulties in the categorisation are concerned with the quasiofficial sources, such as proclamations to the army, especially in the era of competition between the Targowica Confederation (proclamations issued by the Marshal of the Confederation Szczęsny Potocki) and the weakening patriotic centre. It might be added that even formally adopted legal acts were often characterized by journalistic language with instances of attempts to explain the legislature's intention instead of being limited solely to the texts of regulations. ${ }^{21}$

\footnotetext{
${ }^{17}$ Printed: Dyaryusz seymu ordynaryinego pod związkiem Konfederacyi Generalney Oboyga Narodow w Warszawie rozpoczętego roku... 1788/[wyd. Jan Paweł Łuszczewski] Diariusz Sejmowy - 1788-1789 Drukarnia Nadworna, Warszawa w Warszawie: w drukarni Nadwornej J.K.Mci i... Kommissyi Eduk[acyi] Narodowej [po 3 XI 1788]-1790, Dyaryusz seymu ordynaryjnego pod związkiem Konfederacyi Generalney Oboyga Narodow w podwoynym posłow składzie zgromadzonego w Warszawie od dnia 16 grudnia 1791 [właść. 1790]/[wyd. Antoni Siarczyński], w drukarni... Michała Grölla... [1791].

${ }^{18}$ Dziennik Czynności Seymu Głównego Ordynaryinego Warszawskiego pod związkiem Konfederacji Oboyga Narodów agitującego się, partly printed, partly in the form of handwritten protocols.

${ }^{19}$ Comp. AGAD, Archiwum Sejmu Czteroletniego.

${ }^{20}$ AGAD, Archiwum Królestwa Polskiego, sygn. 207 Mowy Jego Kr Mci w ciągu Sejmów 17611793, further as: AGAD, AKP, sygn. 207.

${ }^{21}$ Grześkowiak-Krwawicz, Anna. 2000a. O formę rzqdu czy o rzad dusz? Publicystyka polityczna Sejmu Czteroletniego, Łódź: Instytut Badań Literackich Polskiej Akademii Nauk, p. 7.
} 
Another source of expression, available not only to parliamentary members but, among others, to the whole lesser noble community, were free publicist papers and pamphlets. The period of the late eighties and early nineties brought an unmatched explosion of free prints and pamphlets. The correspondent of Ignacy (?) Potocki expressed himself as follows: "so great is the Rush of writing various things" and asked for protection on the admission of his anonymous letter to one of the leading newspapers. ${ }^{22}$ Anna Grześkowiak-Krwawicz, in recent years the most important interpreter of the eighteenth-century journalism, clearly reflects this common trend: "every writer, grasping a pen, even if in the opinion of their opponents eligible to stay with the Brothers Hospitallers, felt he was a citizen fulfilling his patriotic duty, benefiting from his citizen rights. And as such, they demanded respect for themselves and their views from the other participants of the debate". ${ }^{23}$ Moreover, the possibility of publishing was perceived not only in terms of civil rights but also as such a duty. As an anonymous author wrote, "as a free citizen (...) you do not have anything shameful over the latency of your thoughts about the Republic to please someone or to not daunt someone". ${ }^{24}$ That was a real forum for the exchange of thoughts and ideas, the most vivid and meeting with an instant response. As mentioned, epistolary forms were also applied, for instance, as anonymous letters "of a friend" to "friends", commenting on the diplomatic and political events. ${ }^{25}$ Such letters, reflections and comments were published as free prints or on separate pages of magazines. The main protagonists of political discussion often disclosed their correspondence in the form of prints, using it as a useful propaganda tool. The abundantly published correspondence of Szczęsny Potocki creates an immediate impression of having been addressed to a collective rather than an individual recipient. ${ }^{26}$

There were numerous cases of responses to the "Letters" and "Comments". There were many debating pairs: for instance a discussion between Seweryn Rzewuski and Stanisław Szczęsny Potocki and Ignacy Potocki, between Rzewuski and the Bishop Krasiński, between Tomasz Dłuski and Potocki, rejoinders by

\footnotetext{
22 "tak wielka Gorączka pisania rozmaitych rzeczy panuie". Letter to Ignacy (?) Potocki of 25 May 1791, AGAD, APP, sygn. 279b: Listy do I. (Ignacego Potockiego, Stanisława i Aleksandra Potockiego... oraz do innych osób, 1791, t. VI, k. [chart]104-105.

23 "każdy chwytający za pióro, nawet jeśli w opinii swych przeciwników kwalifikował się do pobytu u Bonifratrów, czuł się spełniającym swój obowiązek patriotą, korzystającym ze swego prawa obywatelem. I jako taki domagał się szacunku dla siebie i swoich poglądów od innych uczestników debaty". Grześkowiak-Krwawicz, Anna. 2000a. O formę..., p. 19.Comp. also broadly p. 39-68.

24 "w wolnym obywatelu (...) nie masz nic haniebniejszego nad utajenie swoich myśli o Rzeczypospolitej dla przypodobania się komuś, albo dla niezrażenia kogoś”. NN, Myśli patriotyczno-polityczne do stanow Rzeczypospolitey Polskiey, na seym 1788. roku zgromadzonych, przez obywatela o wolność i samowładztwo Rzeczypospolitey swoiey gorliwego, spisane, n.p., 1788, p. 4.

${ }^{25}$ Cf. As an example: Reflexye nad Listem Króla Pruskiego od Przyjaciela Przyjacielom przesłane, AGAD, AKP, sygn.. 352, k. 388.

${ }^{26}$ Grześkowiak-Krwawicz, Anna. 2000a. O formę..., p. 54.
} 
Czacki and Wolski to the paper "On the Third of May 1791 Constitution to Zaleski and Matuszewic Esq. Lithuanian parliamentary members" ("O Konstytucji Trzeciego Maja 1791 do JWW Zaleskiego trockiego i Matuszewica brzeskiego, litewskich posłów"), ${ }^{27}$ and finally between Antoni Trębicki and Dyzma Bończa Tomaszewski. ${ }^{28} \mathrm{~A}$ more radical letter would frequently elicit an avalanche of responses. A serious reply to the popular work by Stanisław Staszic "Notes on the life of Jan Zamoyski" is a selection of eight letters published as a collective book in $1790 .^{29}$

Among the journals, on the other hand, in the first place it is necessary to mention the "Gazeta Narodowa Y Obca" ("National and Foreign Newspaper") and "Pamiętnik Historyczno-Polityczny Przypadków, Ustaw, Osób, Miejsc i Pism wiek nasz szczególnie interesujących" ("Historical and Political Cases, Laws, People, Places, and Diary Writings of particular interest to our age"). "Gazeta Narodowa Y Obca" contained reports of parliamentary sessions, the texts of key legislative acts and political news from abroad, infrequent rare journalistic articles published usually in the form of letters to the editor. The "Historical-Political Diary" certainly played the most significant role, due to its editor breaking the purely informative convention of the press at that time, an ex-Jesuit priest, propagator of reforms, Piotr Świtkowski. In particular the articles published since 1788 reflected the political views of the editor. Moreover, there were papers published in French, the "Gazette de Varsovie" and the "Journal Hebdomadaire de la Diète". "Gazeta Warszawska" ("The Warsaw Newspaper") published since 1774, limited itself to the role of a passive informer reporting in particular foreign events and serving as a rather poor stimulant for the discussion. ${ }^{30}$

As can be seen prima facie, the public media discourse includes voices which are much more interesting, more radical towards the centrist position, both on behalf of progressive and conservative parties. The parliamentary debate had a rather conservative, courteous nature, however, suddenly in early May 1791, it abruptly changed its character, becoming radically reformatory. In those days, opponents to the Constitution would often avoid speaking in the Parliament just due to the explicitly

\footnotetext{
${ }^{27}$ Grześkowiak-Krwawicz, Anna. 1992. Za czy przeciw ustawie rządowej? Historia pewnej polemiki. Wiek Oświecenia, 8: Wokót Rewolucji Francuskiej i Sejmu Czteroletniego: 169-184.

${ }^{28}$ Comp. broadly Żbikowski Piotr. 1992. Potępienie i obrona ustawy rządowej z 3 maja 1791 roku. Wokół sporu Antoniego Trębickiego z Dyzmą Bończą Tomaszewskim, In: Ku reformie państwa $i$ odrodzeniu moralnemu człowieka. Zbiór rozpraw i artykułów poświęconych dwusetnej rocznicy ustanowienia Konstytucji 3 Maja 1791 roku, Żbikowski Piotr (ed.), p. 97-118. Rzeszów: Wydawnictwo Wyższej Szkoły Pedagogicznej.

${ }^{29}$ Comp. also Szczepaniec Józef. 1991. Sejm Wielki wobec zagadnień cenzury i wolności słowa, In: Antynomie Oświecenia. Tom specjalny w 200 rocznicę Konstytucji 3 maja, Acta Universitatis Wratislaviensis, Prace Literackie XXXI, Matuszewska Przemysława, Zakrzewski Bogdan (ed.). Wrocław: Wydawnictwo Uniwersytetu Wrocławskiego,p. 155-184, particularly p. 164-168.

${ }^{30}$ Comp. broadly Łojek Jerzy, 1988. Prasa dawnej Rzeczypospolitej. In: Dzieje prasy polskiej. Łojek Jerzy, Myśliński Jerzy, Władyka Wiesław (ed.), 18-22. Warszawa: Interpress, HomolaDzikowska Irena. 1960. Pamiętnik Historyczno-Polityczny Piotra Świtkowskiego 1782-1792, Kraków: Rozprawy i Studia - Uniwersytet Jagielloński.
} 
expressed unity of parliamentarians, declaring themselves as those who voice the will of the nation, and the nation was to be represented directly by "arbitrators" present at the gallery as guests, eager to utter loud words of praise or condemnation. The constitution was adopted in this very climate. Forcible voices against the Constitution, coming from parliamentary circles, later were to take the nature of separate journalist writings, however they would not actually exist in the parliamentary debate itself as it one was to reflect sui generis political correctness, praising the constitution. Incidentally, a few prominent opponents of the Constitution, under the pressure of the public opinion changed their position and published pamphlets expressing their support for the new Constitution and the regulation of the succession to the throne (Adam Rzewuski, Wojciech Turski, Tomasz Dłuski). ${ }^{31}$

Ewa Borkowska-Bagieńska did not hesitate to put forward the thesis that the writing and practical activities of outstanding individuals - the inspirers of change had a significant, and perhaps even the greatest influence on the transformation of the legal awareness of the lesser nobility of the Stanisław Poniatowski period. ${ }^{32}$

\section{Some Aspects of the Discourse on Sovereignty in the Poland of Enlightenment}

\subsection{Sovereignty as a Theoretical Problem}

\subsubsection{Introduction}

The concept of sovereignty rarely appears in the debate in this very wording. Adequate clues used in the analysis also refer to the concept of "free will", and "national will". The terms of "independence" and "self-governing" can be considered synonymous with the concept of sovereignty, similarly to the "majesty" used in the earlier period of time. ("The majesty is thus the highness and dignity of the Republic" ${ }^{33}$ ). Sovereignty is identified with the highest authority. Already at the

\footnotetext{
${ }^{31}$ Comp. at least Lis Rafał, 2012. Między Konstytucją 3 maja a Targowicą. Poglądy polskich republikantów w latach 1791-1793, Czasopismo Prawno-Historyczne, LXIV (2): 161-191 or the discourse around Tomasz Dłuski writing: JW. JP. Tomasza Dłuskiego podkomorzego Generalnego Usprawiedliwienie się przed Publicznością z Manifestu przeciwko Ustawie dnia 3 Maia Ru teraźnieyszego.

${ }^{32}$ Borkowska-Bagieńska Ewa. 2009. O świadomości prawnej szlachty w czasach stanisławowskich i potrzebie jej badania. Studia z dziejów państwa i prawa polskiego, XII, Kraków-Lublin-Łódź: p. 158.

33 “Majestat tedy jest wielmożność a dostojność rzeczypospolitej”. Andrzej Frycz-Modrzewski, cited after: Wachlowski, Zbigniew. 1927. Pojęcie suwerenności w literaturze politycznej polskiej XV i XVI wieku. In: Pamiętnik trzydziestolecia pracy naukowej prof. dr. Przemysława Dąbkowskiego wydany staraniem Kótka Historyczno-Prawnego Stuchaczów Uniwersytetu Jana Kazimierza 1897-1927,. Lwów: skł. gł. Księgarnia Gubrynowicza i Syna, p. 240.
} 
beginning of the sixteenth century, Stanisław Zaborowski invoked the Latin terms "principatus", and "superioritas" as the power in the hands of the nation. ${ }^{34}$

The second of the early theories (16th c.), expressed primarily in the papers by Stanisław Orzechowski and Andrzej Frycz Modrzewski and repeatedly invoked in subsequent periods, was the theory of sovereignty of the law, of course not entirely original, but stressing the element of subordination to the law, not necessarily to the entities which enacted it. ${ }^{35}$ This phenomenon appeared in Polish literature at the beginning of the sixteenth century along with the interpretation of the so called Nihil Novi Constitution $(1505,1538)$ and the 1530 Constitution on the election of King. This theory, contrasted to the traditional sovereignty of the monarch, served the movement for the restriction of royal rights. ${ }^{36}$ The freedom in the free country of Poland was the freedom "under the law" ("there is no freedom without law", as Michał Karpowicz ${ }^{37}$ claimed in the spirit of Locke), which was to bind not only the citizens, but primarily the king. This interdependence was already emphasized in the sixteenth century: "The Republic is to be governed not according to the king's will but pursuant to the written law". ${ }^{38}$ The principle of sovereignty of the law, so characteristic of the Polish tradition, in the legislation of the 4-Years-Sejm (as cardinal laws) took form of a modern at that time rule of law, which in thought of many European countries will not appear until the constitutionalism of "the Spring of Nations" (the executive power operates on the basis of law and to exercise the law). ${ }^{39}$

The noble political writing since the sixteenth century considered the Republic itself as an entity of sovereign power, however over time the nature of this political community changed (the political body). From the sixteenth century until the May Constitution this community was created exclusively by nobles (deputies and senators) and the King, which was the construction of three states acting as Seym ("stany sejmujace"). The sovereignty of the Republic was therefore in some measure divided between the nobles and the King. The King although chosen through free elections, was formally the King of the grace of God, and theoretically the enforcement of a new law that bound the two sovereigns, the nobles and the king, depended on his own will. Hence the popular identification of the sovereign Republic with

\footnotetext{
${ }^{34}$ Wachlowski, Zbigniew. 1927. Pojęcie ..., p. 235-236.

${ }^{35}$ Ibidem, p. 237.

${ }^{36}$ Relevant literature cites at least Makiłła Dariusz. 2010. Idea jedności a koncepcja rozdziału władz w teorii i praktyce ustrojowej Rzeczypospolitej na przełomie XVI - XVII w. In: $W$ kręgu nowożytnej i najnowszej historii ustroju Polski. Księga dedykowana Profesorowi Marianowi Kallasowi. Godek Sławomir, Makiłła Dariusz, Wilczek-Karczewska Magdalena (ed.), 1-20. Warszawa: InterLeones Halina Dyczkowska.

37 "nie masz wolności bez prawa”. Karpowicz Michał, Kazanie o miłości ojczyzny, Wilno, n.d. [1781], no pagination; cited after Grześkowiak-Krwawicz Anna, 2006a. Staropolska koncepcja..., p. 71.

${ }^{38}$ Andrzej Frycz-Modrzewski, cite Wachlowski, Zbigniew. 1927. Pojęcie..., p. 241.

${ }^{39}$ Dziadzio, Andrzej. 2010. Polnische Version des Rechtsstaates vom Ende des 18 Jahrhunderts (System des Verfassungsrechts 1791). In: Parliaments: the law, the practice and the representations. From the Middle Ages to the Present Day. Lisbon 2010, p. 117 and ff.
} 
sovereignty of the law. This situation changed with the moment of the adoption of the Constitution of the 3rd of May. The King ceased to be the third Seym-estate, it became only an organ of the executive power, no longer having such a share in the legislation as before. He remained the King of God's grace and the will of the people, ceased to be a sovereign ruler. Now, formally, the whole nation constituting the Republic as a political community of all states, was entitled to the attribute of sovereignty.

As mentioned above, the issue of external security was emphasized in the second half of the seventeenth century to a greater extent as compared with western definitions. The justifications for the genesis of the social contract also went exactly in this direction. ${ }^{40} \mathrm{~A}$ special connection with the fear that the freedom could be converted into a "yoke of serfdom" in the absolutist states also occurs here. ${ }^{41}$

In the seventeenth century, the understanding of the internal sovereignty became permanently bound with the Parliament of the Republic ("the Republic is founded on the Parliament"), which was expressed both by theory and by political practice. ${ }^{42}$ There was a common conviction that the parliamentary states were the sovereign simply saying - the parliamentary chambers were the carriers of the supreme authority. "This is the realisation of the essence of our freedom. We may enact All Political and Civil Rights, following our will and thus the fortunes of the whole Fatherland, in particular, of each natural person, his assets and life are in our power. We pour this power onto the deputies. Together with the Senate, they enact the Laws in the Parliament". ${ }^{43}$ Members of the Chamber of Deputies were elected by the terrestrial district assemblies (Dietines), officially unanimously, although in the absence of a general agreement the majority choice was accepted. The sources of the Polish representation theory lie naturally in the canon law. ${ }^{44}$ The key role of systemic parliament also reflects the fact that many of the eighteenth-century reform programmes came out from the repair and improvement of the functioning of parliaments. The composition of the Senate, the aristocratic chamber, will be reduced by the future constitution to approx. 130 members: provincial governors, castellans (lesser castellans were frequently also members elected to the lower chamber), diocesan bishops and ministers. The system of the 3rd of May enacting the law on

\footnotetext{
${ }^{40}$ Grześkowiak-Krwawicz, Anna. 2000b. O recepcji umowy społecznej w Polsce w czasach stanisławowskich, Czasopismo Prawno-Historyczne. LII (1-2): 115-116.

${ }^{41}$ Grześkowiak-Krwawicz Anna, 2006a. Staropolska koncepcja..., p. 67.

${ }^{42}$ Borkowska-Bagieńska Ewa. 1992. Nowożytna myśl polityczna w Polsce 1740-1780, Studia z Dziejów Polskiej Myśli Politycznej, Vol. IV. Od reformy państwa szlacheckiego do myśli o nowoczesnym państwie, Toruń: p. 34-35.Comp. also Bardach Juliusz. 1983. Sejm..., p. 134-147.

${ }^{43}$ “Tu jest całey wolności naszey użycie. Wszystkie Polityczne i Cywilne Prawa możemy podług naszey woli stanowić, a tak całey Oyczyzny losy, każdego w szczególności Obywatela majątek i życie, są w mocy naszey. Tę moc zlewamy na posłów, Posłowie z Senatem stanowią Prawa na Seymie”. NN, Zbiór pism do których były powodem uwagi nad życiem Jana Zamoyskiego. Ósme Pismo. Myśl względem poprawy formy rządu, b.m.w., Roku 1790, p. 31.

${ }^{44}$ Grzybowski Konstanty. 1959. Teoria reprezentacji w Polsce epoki Odrodzenia, Warszawa: Państwowe Wydawnictwo Naukowe, p. 22.
} 
the Parliament ${ }^{45}$ would also affect the decline in the role of this body, limiting the powers of the monarch connected with legislative power - the successor Stanisław August would have to appoint lay senators just amongst twice the number of candidates proposed by regional assemblies.

It is also required to invoke another theoretical problem - the local assemblies (Dietines) vested a specific role by the existing legal system. Between the midseventeenth and mid-eighteenth century their importance in the political practice grew, when, due to interruption of central parliaments, Dietines took over many of the executive tasks of the Parliament, even the enlisting of troops. Thus, there was a kind of "sovereignty decentralization". ${ }^{46}$ By expressing instructions for parliamentary members, Dietines formed real boundaries for their parliamentary activity. Members of Parliament feared exceeding assumptions and breaking the sworn instructions - a kind of a "general will" tool; feared going beyond these boundaries, being aware of their obligation to report and justify themselves at the so-called reporting Dietines where they had "to account before the nation" for the actions of the Parliament. These were the local assemblies (Dietines) that Rousseau understood as a link between the inalienability of sovereignty with the representative system, as the lesser nobles did not renounce their sovereignty in favour of their representatives, providing them with a sort of a mandat imperatif. ${ }^{47}$ Finally, the local assemblies (Dietines) as the final nexus were to accept the Constitution of the 3rd of May along with the comprehensive reform, which they did with the majority of $82 \%$ in February 1792, proving the invalidity of the stereotype of an exclusively conservative nature of local lesser nobles' assemblies. ${ }^{48}$ This may have been the reason for the mentioned Wojciech Turski ${ }^{49}$ to change his attitude towards the Constitution so radically. The derivative of this important function of Dietines (and understanding the role of Members only as "the lips of the provincial confreres" is the thesis sporadically put forward in the literature in relation to the sovereign role

\footnotetext{
${ }^{45}$ Art. IV, Seymy (Prawo o Sejmach), Actum in Curia Regia Varsaviensi Die Vigesima Octava Mensis Maij, Anno Domini Millesimo Septingentessimo Nonagesimo Primo, Zbiór Ustaw Seymowych w Warszawie; also published: Volumina Legum, Wydawnictwo Komisyi Prawniczej Akademii Umiejętności w Krakowie, t. (Vol.) IX, Kraków 1889, p. 250-266.

${ }^{46}$ Bardach Juliusz. 2002. Historia ustroju i prawa polskiego, Warszawa: Państwowe Wydaw. Naukowe, p. 248.

${ }^{47}$ In fact in contrast to the position of the court which appealed in letters to councils to equip deputies in plena potestas, the free mandate guarantees freedom of decision in the Parliament. Naturally, closely linking local councils with the preferred allowance, limitata potesta. Bardach Juliusz. 1983. Sejm..., p. 146. Comp. also:Michalski Jerzy. 1983. Z problematyki republikańskiego nurtu w polskiej reformatorskiej myśli politycznej w XVIII w. Kwartalnik Historyczny, 90: 331-332; Uruszczak Wacław. 2010. Poselstwo sejmowe w dawnej Polsce. In: Drogi i bezdroża nauk historyczno-prawnych, Małecki Marian (ed.), 52-56. Bielsko-Biała: Wyższa Szkoła Administracji.

${ }^{48}$ Szczygielski Wojciech, 1994. Referendum trzeciomajowe. Sejmiki lutowe 1792 roku, Łódź: Wydawnictwo Uniwersytetu Łódzkiego, passim.

${ }^{49}$ Lis Rafał, 2012. Między Konstytucją..., p. 173.

${ }^{50}$ Bardach, Juliusz. 1983. Sejm..., p. 146.
} 
of the provinces or a quasi-federal system of the Republic (for instance by Stanisław Płaza). ${ }^{51}$

Generally, a strictly theoretical discussion over the issue of sovereignty is not too extensive; Anna Grześkowiak-Krwawicz stresses that this may have arisen from the practical orientation; "Polish authors were less interested in philosophical considerations on the origins of human societies and more on the conclusions stemming from them. Hence, they stressed hardest the fact that power was entrusted with the monarch - somehow positioning the nation over the monarch - and showing the sovereignty of the nation itself'. The latter was not a consequence of the reception of foreign theories, but of "Polish practice, in which the sovereignty of the nation (lesser nobility) was the reality". ${ }^{52}$ Hence, the right of the nation to resist the monarch in the event of a breach of his obligations was never questioned. The choice of the monarch ensued through "viritim" election, direct selection, and additionally, admittedly theoretically, there existed the possibility of convening equestrian parliament to protect the rights, which could bring together the mass of the nobility. ${ }^{53}$ Mutual agreement was in Poland not a theoretical construction, but a purely living practice, since a visible contract was concluded with each elected ruler as pacta conventa. ${ }^{54}$ Therefore, to the Frenchman's accusation: "vos non habetis regem", the Pole might have answered: "sed vox rex habet". ${ }^{55}$ At the same time, the sui generis paradox is that the Poles needed an elective king, because this phenomenon raised their own prestige, "they needed a king just to elect him", what emphasized the sovereignty of the nation. ${ }^{56}$

${ }^{51}$ Lityński Adam. 1985. O reformach sejmikowania 1764-1793. Czasopismo-Prawno-Historyczne, XXXVII (2): p. 260-262.

52 "autorów polskich mniej interesowały filozoficzne rozważania nad początkami społeczeństw ludzkich, a bardziej wnioski z nich wypływające. Stąd najsilniej podkreślali oni fakt powierzenia władzy monarsze - stawiający niejako społeczeństwo ponad monarchą i ukazujący suwerenność tegoż społeczeństwa (...) [będącej skutkiem],,praktyki polskiej, w której zwierzchnictwo narodu (sc. szlacheckiego) było rzeczywistością". Grześkowiak-Krwawicz, Anna. 1987. Polska myśl polityczna lat 1772-1792 o systemie władzy monarchii absolutnej. Kwartalnik Historyczny, z. 3: p. 45. Similarly, in other work: Grześkowiak-Krwawicz, Anna. 2010. Polskie poglądy na monarchie europejskie. In: Rozkwit i upadek I Rzeczypospolitej, Butterwick Richard (ed.), Warszawa: Bellona, p. 151: "Poles treated political topics in a very pragmatic way", hence they were less interested in the Republican model, which - they believed - they knew from experience, drawing the attention of monarchical governments. Comp. also Lis Rafał, 2012. Między Konstytucją..., p. $173-174$.

${ }^{53}$ Olszewski Henryk. 1985. Sejm konny. Rzecz o funkcjonowaniu ideologii demokracji szlacheckiej w dawnej Polsce. Czasopismo Prawno-Historyczne, XXXVII (2): 225-242.

${ }^{54}$ Grześkowiak-Krwawicz, Anna. 1987. Polska myśl..., p. 46. Grześkowiak-Krwawicz, Anna. 2000b. O recepcji..., p. 109-125.

${ }^{55}$ Grześkowiak-Krwawicz, Anna. 1987. Polska myśl..., p. 57.

${ }^{56}$ Grześkowiak-Krwawicz, Anna. 2003. Czy król jest potrzebny w republice? Polscy pisarze polityczni wieku XVIII o miejscu i roli monarchy w Rzeczypospolitej. Zarys problematyki. In: Dwór a kraj między centrum a peryferiami władzy. Materialy konferencji naukowej zorganizowanej przez Zamek Królewski na Wawelu Instytut Historii Uniwersytetu Jagiellońskiego, Instytut Historii Akademii Pedagogicznej w Krakowie $w$ dniach 2-5 kwietnia 2001, Skowron Ryszard (ed.), Kraków: Zamek Królewski na Wawelu. Państwowe Zbiory Sztuki, p. 475. 


\subsection{2 'Sovereignty' in Media and Free Prints Debate}

One of the most distinguished voices in the public debate belonged undoubtedly to Hugo Kołłątaj, the "Polish Robespierre." He did not use the notion of sovereignty in his writings, but formulated his recommendations for the creation of a system with Parliament as "the highest authority", authorized not only to enact the law, but also to the executive power, the Seym debating in "a parliamentary way". Undermining the existence of a free government in a country where some people remain in feudal captivity, Kołłątaj differentiated "human freedom" from "governmental freedom", political one,${ }^{57}$ the latter he awarded to nobles and burghers, what will be discussed more extensively in the following parts.

Later discussions, from the time following the adoption of the Constitution of May, would be in relation to the issues of freedom, full of paradoxes. On the one hand, the protagonists would raise that the Constitution allowed freedom to be maintained (an important aspect is this direct reference of reformers to external threats, which was an important factor in the process of the adoption of the Constitution; it is worth reminding that reading foreign news dispatches on the $3 \mathrm{rd}$ of May, 1791 helped to build the atmosphere of terror and a sense of a need for reform). Its antagonists would stress that it was a "monarchical" constitution which had taken the freedom away from the Nation. ${ }^{58}$ Sovereignty in the debate thus far would be identified with freedom.

\subsection{3 'Sovereignty' in Parliamentary Debate}

Similarly, the term of "sovereignty" is not used in the parliamentary debate. Occasionally, it refers directly to the supreme authority ("Two Nations Majesty preserved itself the supreme authority in the Parliaments" ${ }^{59}$ ). The terms of "selfgovernance" (e.g. "The laws of the Polish Republic self-governance") ${ }^{60}$ or "independence" or else "highest independence" can be recognized as equivalent notions.

There are, in turn, many references to the element, which the author considers to be complementary to the sovereignty, i.e. freedom. Such formulations had been present in the discussion since the first sessions of the Parliament, as for instance in the acceptance by members of the confederation formula. This prevented

\footnotetext{
${ }^{57}$ Grześkowiak Krwawicz, Anna. 2006a. Staropolska koncepcja..., p. 80.

${ }^{58}$ Copies of the letters of Stanisław Szczęsny Potocki, AGAD, AKP, pudło (box) 90.

59 "Maiestat Oboyga Narodów zachowawszy sobie najwyższą władzę w Seymach”. Głos Jaśnie Wielmożnego Imci Pana Raczynskiego Marszałka Nadwornego Koronnego i Generała WielkoPolskiego, Roku 1788, Dnia 24 Października Na Sessyi Seymowey miany, Zbiór mow i pism niektórych w czasie Seymu Stanów Skonfederowanych Roku 1788, Tom I, w Wilnie w Drukarni J.k. Mci przy Akademii, p. 285.

${ }^{60}$ Głos Jego Kr. Mości na Sessyi Seymowey dnia 20. Lipca 1789. Miany, AGAD, AKP, sygn. 207, k. [chart] 813 (443).
} 
renouncement of the Parliament by single members and resulted in the procedure of adopting resolutions by a majority. Although this was a kind of a denial of the already existing 'freedom' of the deputies, the members were aware of the seriousness of the moment and agreed to this restriction, seeing it as an act of expression of the Republic's self-governance and of a mutual trust between the king and the nation. The court chamberlain of the king, Marcin Slaski, said: "With freedom and liberty born, let's be independent, to any prejudice not being bound to hand the spirit of Patriotism listening only to inspiration, so we direct our actions to that what is always appropriate for the Common good". ${ }^{61}$ Troop enlargement enacted in autumn 1788 is also to serve as a protection of the "free constitution" and the "free Government". ${ }^{62}$ Military power cannot be used "for the suppression of Liberty. This is indeed Freedom, which has elements of the Republican Government in Our Nation, and has always been the goal of common solicitude". ${ }^{63}$

Then for the Throne it is glorious "to govern the free people, even as it would blemish wanting to be despotic. Prevail Your Royal Majesty over the hearts of citizens arbitrarily, leaving the mind of each free from any influence and of any foreign subordination", as a Livonian member Kublicki appealed to the monarch. ${ }^{64}$ Member Czetwertyński outlined, that equality introduced "in the Republican state" under the reign of King Stanisław August "established the crucial freedom in that Republican State", the King is the one who "effectively opened freedom for the Nation" ${ }^{65}$

${ }^{61}$ "Z $Z$ wolności i do wolności zrodzeni bądźmy niepodległemi, do żadney z uprzedzeniem nie wiążąc się strony, ducha tylko Patryotyzmu słuchaiąc natchnienie, tak nasze kieruymy czyny, aby zawsze stosowne dobra Powszechnego były". Mowa Jaśnie Wielmożnego Imi Pan Ślaskiego Podkomorzego Nadwornego J. K. Mci, Posła z Województwa Krakowskiego na Sessyi przed Stanami Skonfederowanemi Rzeczypospolitey, Dnia 16 Października Miana, Zbiór mow i pism niektórych w czasie Seymu Stanów Skonfederowanych Roku 1788, Tom I, w Wilnie w Drukarni J.k. Mci przy Akademii, p. 68-69.

${ }^{62}$ Głos Jaśnie Wielmożnego Ignacego Potockiego M.N. W.X.L. na Sessyi Seymowey dnia 24. Października 1788-Roku o Rządzie nad Woyskiem, Zbiór mow i pism niektórych w czasie Seymu Stanów Skonfederowanych Roku 1788, Tom I, w Wilnie w Drukarni J.k. Mci przy Akademii, p. 152.

63 "na potłumienie Wolności. Ta to iest zaiste Wolność, która od pierwiastków Rządu Republikantskiego w Narodzie Naszym, była zawsze celem troskliwości powszechney". Głos Jaśnie Wielmożnego Imci Pana Raczynskiego Marszałka Nadwornego Koronnego i Generała Wielko-Polskiego, Roku 1788, Dnia 24 Października Na Sessyi Seymowey miany, Zbiór mow i pism niektórych w czasie Seymu Stanów Skonfederowanych Roku 1788, Tom I, w Wilnie w Drukarni J.k. Mci przy Akademii, p. 283.

64 “rządzić wolnym ludem, równie iak byłoby skazą chcieć być samowładnym. Panuy W.K. Mość nad sercami Obywatelów samowładnie, umysł każdego zostaw wolnym, i od wpływu iakiegokolwiek, i od obcey podległości”. Przymówienie się Za Proiektem Kommissyi Woyskowey Jaśnie Wielmożnego Kublickiego Posła Inflantskiego, Zbiór mow i pism niektórych w czasie Seymu Stanów Skonfederowanych Roku 1788, Tom I, w Wilnie w Drukarni J.k. Mci przy Akademii, p. 206.

${ }^{65}$ równość wprowadzona "w Stan Republikancki” za panowania Stanisława Augusta "ustanowiła dopiero w tymże Stanie Republikanckim istotną wolność", król jest tym, który "skuteczną Narodowi otworzył wolność". Głos JO Xcia imci Antoniego Czetwertyńskiego Chorążego i Posła Bracławskiego, Na Sessyi Seymowey Dnia 24. Października 1788. Roku miany, Zbiór mow i pism 
Finally, freedom as a purpose for the enactment of the Constitution was indicated in the anniversary royal speech held in 1792: "the real and only objective to establish the new form of Government was nothing else, but (if possible for humans) for all Polish Nationals to share equally in the freedom and the security of their property." ${ }^{66}$ Members expressed their conviction that the Polish system of government guaranteed this freedom, which is now threatened, whereas thus far, after all, it seemed that "it's enough to be a Pole to be free". ${ }^{67}$

\subsection{4 'Sovereignty' in Legal Acts}

"The Rules for improvement of the form of government" (Zasady do poprawy formy rzadu) of December 1789 indicated key constitutional principles, "the authorities and the laws of the Republic". The essential duty of the state included "the right and power of making acts, not being subject to any other, only this, which itself represents the Republic." "The rights and authorities that they have is appropriate" entrusted by the Republic to the Parliament and to Dietines - regional assemblies; "The will of the Republic as to the legislative and parliamentary power by a matter of unanimity or a different majority shall demonstrate"; absolute unanimity was required in matters concerned with the cardinal laws. The Republic entrusted the execution of power to the King and the highest guard. Officials were responsible for their duties to the Republic. "The Republic in a free and republican composition is empowered" 68 to execute its authorisations.

The inviolable cardinal rights (Prawa kardynalne niewzruszone, 1791) of the 8th of January, 1791 declared the Republic of Poland "free and independent of anyone". The Republic creates a single indivisible body exercising its tasks specified in art. VI "in a state of nobility" through it. Any foreign intervention "opposing independence of the Republic and its derogatory self-inertia" was considered invalid.

niektórych w czasie Seymu Stanów Skonfederowanych Roku 1788, Tom I, w Wilnie w Drukarni J.k. Mci przy Akademii, p. 301, p. 303.

66 "prawdziwy i jedyny cel utworzenia tey nowey Formy Rządu nie był inny, tylko (ile po ludzku być może) wszyscy Narodu Polskiego Współ-Ziomkowie równie byli uczestnikami udziału wolności i ubezpieczenia własności swoich”. Mowa Jego Królewskiey Mci Dnia 3go Maia Roku 1792 w Kościele Świętego Krzyża miana, AGAD, AKP, sygn. 207, k. [chart] 1337 (683).

67 “dość bydź Polakiem, by bydź wolnym”. Przymówienie się Jaśnie Wielmożnego Stanisława Mieroszewskiego Posła Krakowskiego na Sessyi Seymowey Dnia 21. Lutego Roku 1791 Sessya 38 dnia 21 Lutego 1791 Roku, AGAD, ASCz, sygn. 19, k. [chart] 652od.

68 "prawo i władzę czynienia ustaw, niepodlegania żadnym innym, ieno tym, które sama Rzeczpospolita stanowi". "Prawa i władze sobie właściwe" powierzyła Rzeczpospolita sejmom i sejmikom; "wola Rzeczypospolitey, co do prawodactwa, władzy seymuiącey poruczona, podług gatunku materii iednomyślnością, lub różną większością okazywać się będzie"; jednomyślność bezwzględnie wymagana była przy materiach z zakresu praw kardynalnych. Wykonanie praw powierzyła Rzeczpospolita królowi i najwyższej straży. Urzędnicy za swe obowiązki odpowiadali przed Rzecząpospolitą. Uprawnienia swe "Reczpospolita w składzie wolnym i republikanckim czynić mocna iest”. Zasady do poprawy formy rządu, Volumina Legum, Wydawnictwo Komisyi Prawniczej Akademii Umiejętności w Krakowie, t. IX, Kraków 1889, p. 157-159. 
Finally, nothing "in the Republican state for law and authority reckoned not to be, that would not flow from the expressed will of the Republic on the parliaments: no formal authority orders nobody to carry out orders to coerce it will be, do they not order right: it will not be able to allow itself and anyone what the law prohibits" ${ }^{69}$ Therefore there exists a visible link between sovereignty and state independence. Thus the "Cardinal Rights" also constitute another post figurative wording of the idea of "the will of the Republic".

Based on the text of the Government Act of the 3rd of May, the issues of the sovereignty of the State and of the nation can be distinguished. Nothing surprising can be found in the understanding of sovereignty of the State; however, attention shall be drawn to the fact that those provisions were adopted in a specific intention to manifest the independence from foreign powers - read: the Russian Empire hence the emphasis in the preamble to the Constitution that the nation wants to free itself "from foreign oppression" to recover "its political existence, internal and external independence of the nation." The sovereignty of the Republic was the result of sovereignty of the nation, the entity which was entitled to the highest authority in the State. The Constitution did not contain direct references to the State, however the "countries of the Commonwealth" are referred to in articles III and IV.

In turn, the principle of sovereignty of the nation was proclaimed in art. V which read: "All authority in a human society takes its origin in the will of the nation" ("Wszelka władza społeczności ludzkiej początek swój bierze z woli narodu"). The Preamble to the Constitution defined sovereignty as "the external independence and internal freedom."

Although the inspiration, coming from the relevant article II of the French Declaration of Rights of Man and Citizen of 1789 is clearly visible in the regulations, Polish solutions are far from any radicalism. After all, the Constitution maintained the division into social states, the monopoly of the lesser nobles in the field of political rights, not undermined to a greater extent by the appointment of plenipotentiaries of towns and cities to the Parliament with an advisory vote. This confirmed and put into life the principles already present in the fundamental cardinal laws of January 1791.

\footnotetext{
69 “w państwach Rzeczypospolitey za prawo i władzę poczytane bydź nie ma, coby nie wypływało z wyraźney woli Rzeczypospolitey na seymach: żadna urzędowa władza nikomu rozkazywać i do wykonania rozkazów zniewalać nie będzie mogła, czego nie rozkazuią prawa: nie będzie mogła pozwalać sobie i nikomu tego, czego zakazuią prawa". Prawa kardynalne niewzruszone, Volumina Legum, t. IX, p. 203-204.
} 


\subsection{The Nation}

\subsubsection{Introduction}

As already mentioned, in the political practice, the expression of beloved liberty is the right to decide freely on one's matters through the best representatives of the nation, as lesser nobility perceived themselves; the right to articulate the needs of the whole community through the lips of nobles.

At that time it was the quest for freedom, originating from lesser nobles, that was to shape the system of balance between the state of lesser nobility (not the state of aristocracy; it should be emphasized that the Polish nobility did not carry separate princely titles, those could only come from foreign monarchs and it was believed that "the nobleman on his farm is equal to the governor", although, of course, political practice turned masses of impoverished gentry into ideal clients of magnates) and the king, who gradually gave away his prerogatives by granting privileges to the estate of lesser nobility. In the seventeenth and mid-eighteenth centuries, the state of equilibrium was in practice utterly destroyed, leading to such pathological situations as notorious breaking off of the Parliament by corrupt members without any decisions being taken, buying royal election results by foreign courts, which resulted in the weakness of the monarch and an empty treasury, corruption of those holding high public functions, for instance the case of prince Adam Poniński, a gambler maintained by Moscow. This system in the conservative papers is referred to as republican,$^{70}$ the republic with an elected monarch - often just a figurehead. Modern scholars write in agreement about the system of government at a later stage of development of the First Republic as a "monarchia mixta".

It is a paradox that the authors of the Polish Enlightenment already well familiar with Montesquieu and Rousseau papers easily employed the concept of the nation, while their majority accepted that the actual exercising of the rights of the sovereign was in the hands of one social class, which made up approximately $8 \%$ of the population. Some political activists of the $60 \mathrm{~s}$ and $70 \mathrm{~s}$, and then of the period of the Great Parliament, already represent another generation, educated in a different manner (the role of Piarist schools), conscious of cameralistic and mercantilist processes, taking place in Europe, as well as, the transformation of law, especially of criminal law. ${ }^{71}$ However, the struggle for the change of the convictions on a specific role of the nobility, deeply established in the literature - in the free prints and sources related to the functioning of the Parliament - was to be extremely difficult. This referred not only to the social issues, but rather to the overall way of thinking of an average lesser nobleman, rather reactive and slow, which is reflected, for instance,

\footnotetext{
${ }^{70}$ This concept was subject to evolution. While Janusz Maciejewski in his studies (e.g. Maciejewski, Janusz. 1977. Pojęcie..., p. 21-41) uses them to determine the so-called Bar Confederation nobilitygroup, contesting the baronial established order, so much so that in the day of the Great Parliament, and therefore approx. 20 years later, republicans are customary supporters for retaining elections and supporters of traditional, conservative political solutions.

${ }^{71}$ Borkowska-Bagieńska Ewa. 1992. Nowożytna myśl..., p. 40.
} 
in the debate over the draft of "the Collection of Laws". ${ }^{72}$ At the same time, very special demands of the reforms, different than those in France or German countries were not directed against absolutism or the "omnipotence of the State which gave them [the reformatory thoughts] an individualistic coloration", but exactly against the Sarmatian individualism, hence their deep social or even pro-"etatism" character.

Even though the selected authors are aware of the need to reform the nation towards " turning the people into citizens", as for instance Adam Rzewuski, ${ }^{73}$ they accept the necessity to carry out a slow, not revolutionary reform. The legislation takes time, "it cannot proceed to effecting these great intentions yet [the abolition of social classes]."74

Around 1790, voices to improve the legal status of townspeople gained in force. An alliance was formed between the most radical deputies, such as Ignacy Potocki, ${ }^{75}$ and the representation of townspeople. It was not limited to writing papers and drawing up manifestos. One of the more marked events that should be noticed was the so-called "Black procession" under the leadership of Jan Dekert, the Mayor of the City of Warsaw that passed along the streets of the Capital City to the Royal Palace, where the King was handed a petition of the bourgeois state. These actions coincided with the submission of one of the most liberal reform drafts to be discussed later.

While the voices for equal bourgeois empowerment were relatively numerous in this phase of the social and political debate, there were no extensive references to raising the status of peasants to the rank of "citizenship". This does not mean that the peasants' state did not appear in journalism, but these were mainly appeals for a more humanitarian way to demand the fulfilment of peasants' obligations towards the owners of villages, the settlement of mutual obligations in contracts. Piotr Świtkowski painted very visual pictures in "The Diary ...". ${ }^{76}$ Chancellor Andrzej Zamoyski, a Lithuanian Vice-Chancellor Joachim Chreptowicz and the nephew of King, Stanisław Poniatowski belonged to a small group of reformers.

\footnotetext{
${ }^{72}$ Ibidem, p. 41-42.

${ }^{73}$ [A.W. Rzewuski] Adama Wawrzeńca Rzewuskiego Kasztelana Witebskiego o formie rządu republikańskiego myśli, w Warszawie 1790. w szczególności: Rozdział III. O edukacji, p. 25-61. An edition of the work of Rzewuski with an introduction by W. Bernacki and footnotes by M. Sanek were recently published, Kraków 2008.

74 “jeszcze do dokonania tych wielkich zamiarów [likwidacji klas] przystąpić nie może”. [A.W. Rzewuski], Adama Wawrzeńca..., p. 168.Comp. alsoWalicki, Andrzej. 2000. Idea narodu..., p. 36-37.

${ }^{75}$ However he was a Potocki supporter for preserving the essential role of the nobility, while promoting the bourgeoisie. "Equality is not taken at this point for chimeric and even according to the natural order unlike the equality of fortunes and riches, but only for the equality that every person who lives in the community gives equal right to free and safe use of the property to a person, property and his income". Zabawy Przyjemne i Pożyteczne, 1771, t. V, p. 415, t. VI, p. 227. Comp. Janeczek Zdzisław. 2007. Idea wolności w mowach i pismach Ignacego Potockiego. In: Spory o państwo $w$ dobie nowożytnej: między racja stanu a partykularyzmem, Anusik Zbigniew (ed.), Łódź: Wydawnictwo Uniwersytetu Łódzkiego, p. 201-214, in particular p. 206-207.

${ }^{76}$ Homola-Dzikowska Irena. 1960. Pamiętnik...p. 54-62, p. 69-92.
} 
The most radical demands appealed to do away with the serfdom; however, commentators underline that even those had a very restricted character, pushing for no more than the liberation of peasants, without granting them any land property, which might have been exclusively the right of townspeople. ${ }^{77}$ In his well-known brochure even Jan Baudoin de Courtenay suggested the attendance of "eloquent, reasonable and those familiar with the needs of their state" peasants' representatives in the Parliament. However, he foresaw a long way for them, before they would save enough money to purchase some "settlement". ${ }^{78}$

The nobility will have a more democratic attitude toward their own social group. Attempts to restrict the rights of the non-property nobility will cause fierce debates. It is also worth mentioning that understanding the nobility as a sovereign was connected with the specificity of the Polish political system, i.e. the activity of the regional councils (the Dietines) consisting in the preparation of instructions for members for the meetings of the next parliament. It was an element of direct democracy invoked even by Rousseau. In practice, perhaps, it less reflected the spirit of local decision-making, as during that part of the parliamentary meeting when the instructions were laid out, it was usually already attended by a small part of the local gentry. Nonetheless, breaking the instructions could be a serious accusation; as we shall see, the issue will appear in the procedure for the adoption of the Constitution of the 3rd of May.

\subsection{2 'The Nation' in the Media and Printed Materials}

The concept of the nation is extremely popular in the analysed debate. However, very rarely did the publicists dare to define the concept, here it is necessary to recall the liberal definition of Franciszek Jezierski, "the nation is the gathering of people having one language, customs and manners contained in one general legislation for all citizens. The people and the government of the nation are separate things though it seems that a nation cannot be without a country for it is without its habitat, and again that the country cannot be without a government". ${ }^{79}$ Similarly, to Father Hajewski the nation is " a collection of people within certain limits of settled land, a compound of will, power and riches for the common needs and the help of the united", but the author adds the estate elements "in various divisions of the estate

\footnotetext{
${ }^{77}$ Borucka-Arctowa Maria. 1957. Prawo natury jako ideologia antyfeudalna, Warszawa: Państwowe Wydawnictwo Naukowe, p. 198-200.

${ }^{78}$ Ciąg dalszy uwag ogólnych nad stanem rolniczym i miejskim. Uwaga II, n.p., n.d., quot. after: Woliński Janusz, Michalski Jerzy, Rostworowski Emanuel (ed.). 1955. Materiaty do Sejmu Czteroletniego, Wrocław, Vol. I, p. 128, 133.

79 "naród jest zgromadzenie ludzi mających jeden język, zwyczaje i obyczaje zawarte jednym i ogólnym prawodactwem dla wszystkich obywatelów. Naród a rząd narodu są osobne rzeczy lubo zdaje się, że naród nie może być bez kraju, to jest bez swojego siedliska, i znowu że kraj nie może być bez rządu”. F.J. Jezierski, Wybór pism, Warszawa 1952, p. 217.
} 
under the law and under the care of the highest sovereignty remaining".$^{80}$ Therefore, it suggests an enigmatic sovereign to which nation is subject; in an earlier, already cited passage of speech he acknowledged, however, that taking care of public affairs is "the citizens" " matter.

For a vast majority of writers the decision-making force rests in the will of the people. Often the concept of the nation occurs in a phraseological connection with the adjective "free". ${ }^{81}$ It is only nation that can decide and choose between a system of "self-empowered government" and "a free government". ${ }^{82}$ The issue of the power of the whole nation with regard to such crucial decisions will be present in the literature critical of the Constitution of the 3rd of May, seizing onto the allegations that in the parliamentary debate, described broadly below, there appeared already on the 3rd of May: Members of the Great Parliament could only be interpreters of the decisions that were made at regional assemblies (Dietines) and had no right to break parliamentary instructions regarding maintenance of elections to the throne. It is nation gathered at regional councils that is the sovereign; these regional councils "are interpreters of the will of the people and the opinion coming under parliamentary decision". ${ }^{83}$ Members, even in a majority of "several dozen", according to the opponents of the Constitution did not have the right to free the king from the oath of pacta conventa. ${ }^{84}$ This element, an abuse of members' power, opposing of the Sejm to the nation (as well as a group of Warsaw "madmen" to the worthy of trust nobleman who settled in the provinces), appear relatively frequently in a discussion related to the Constitution. Also, supporters of the constitution did not question the meaning of the instructions, "but through a different interpretation merely tried to prove that the members did not act against them". ${ }^{85}$ The nation is all the nobility.

\footnotetext{
${ }^{80}$ [naród jest] "zbiorem ludzi w pewnych granicach ziemi osiadłych, związkiem woli, sił i dostatków dla wspólnych potrzeb i pomocy zjednoczonych (...) w różnych podziałach Stanów pod prawem i opieką naywyższey udzielney Zwierzchności zostaiących”. Mowa Dowodząca: że przepisy nauk od Prześwietney Komissyi Edukacyi Narodowey dla Szkół Publicznych podane są nie tylko użyteczne Kraiowi ale też potrzebne w szczególności Obywatelom przez Ja. X. Daniela Haiewskiego Kanonika Kijowskiego Nauczyciela Wymowy w Szkołach Akademickich Warszawskich przy rozpoczęciu rocznych nauk dnia 29 września 1790 Roku miana, Bibliotek PAN Kraków, Rps. 177, k. 27.

${ }^{81}$ Kołłątaj, Rzewuski, Konarski. Comp. Pepłowski Franciszek. 1961. Słownictwo..., p. 108.

${ }^{82} \mathrm{M}$. Wielhorski, O przywróceniu dawnego rządu według pierwiastkowych Rzeczypospolitej ustaw, n.p., 1775, p. XIII - XVII.

83 "są thumaczami woli narodu i zdania przychodzącego pod decyzją sejmową". JW. JP. Tomasza Dłuskiego podkomorzego Generalnego województwa lubelskiego i z tegoż Województwa Posła Sejmu Walnego Warszawskiego Usprawiedliwienie się przed Publicznością z Manifestu przeciwko Ustawie dnia 3 Maia Ru teraźnieyszego 1791 nastąpioney w grodzie warszawskim zaniesionego, no pag. A copy has been used from the University Library in Torun., sygn. Pol. 8.III.854, Nr. 22.

${ }^{84}$ Dyzmy Bończy Tomaszewskiego komissarza cywilno-wojskowego wojew. Bracławskiego nad Konstytucją i rewolucją dnia 3 Maja uwagi, n.p., n.d., p. 11.

${ }^{85}$ Grześkowiak-Krwawicz, Anna. 2012. Czy rewolucja może być legalna? 3 maja w oczach współczesnych, Warszawa: Wydawnictwo DiGA. p. 71. Comp. also p. 68-74.
} 
And at the same time solely and exclusively the nobility. As it turns out, also in an open public disccusion the concept of the nation will be reduced to the nobility only. Just a few authors postulate a wider look at the nation. Piotr Świtkowski, the publisher of the "Diary" belongs to this group. He defined the nation as "the whole universality of the Polish nation, consisting of all the states," and imposing the task on the legislature of "giving privileges not just to one state but to the whole nation" ${ }^{86}$ At the beginning of the Great Parliament session, Świtkowski wrote with much hope: "Now another stage has opened. The nation becomes suddenly independent and grounds its self-government forever". ${ }^{87}$ The "Diary" eagerly rendered its columns available for publications, supporting the reform of the townspeople's legal status. $^{88}$

Stanisław Staszic, of bourgeois origin, expressed his opinion in the matter under consideration clearly in his "Warnings for Poland" ... where he concluded: "If the nobility state in the existing circumstance cannot easily and quickly agree to the abolition of the feudal government, and to the establishment of a true Republic, covering the whole nation, and based on the universal law, at this time, the quickest, the easiest and in the present circumstances the surest manner to preserve the nation: is to establish the omnipotence (..) The nation with the feudal or else lesser nobles' government cannot maintain their power". ${ }^{89}$ An anonymous author of "Thoughts on improvement of the form of Government", said these words: " the free government is of this importance that no one person, but the nation is the heir to the country. The nation is nearly everywhere divided into three states: peasants, burghers and lesser nobles. This nation either in all three states, or in two of them or else in one state places the superior national power" 90 ; however, in Poland "the knights' estate with its offices (the Senate and the King) holds the national government." ${ }^{1}$

\footnotetext{
${ }^{86}$ jako "całą powszechność narodu polskiego, składającą się ze wszystkich stanów”, i nakładając na prawodawcę zadanie "upomyślnienia nie jednego tylko stanu, ale całego narodu". Pamiętnik Historyczno-Polityczny, 1789, II, p. 955, p. 856.

87 “Teraz insza otworzyła się scena. Naród zostaje nagle niepodległym i gruntuje samowładztwo swoje na wieki”. Pamiętnik Historyczno-Polityczny, 1788, II, p. 1050.

${ }^{88}$ Homola-Dzikowska Irena. 1960. Pamiętnik...p. 198-204.

89 “Jeżeli stan szlachecki w nadarzonej okoliczności nie potrafi się łatwo i prędko zgodzić na zniesienie rządu feudalnego, a na ustanowienie prawdziwey Rzeczypospolitey, cały Naród obeymującey, i na powszechnym prawie zasadzonej, na ten czas sposób najprędszy, nayłatwieysz a w teraźnieyszych okolicznościach dla zachowania Narodu naypewnieyszy: Ustanowić jednowładztwo (..) Naród z rządem feudalnym czyli z szlacheckim dzisiay żadnym sposobem utrzymać się nie może". Staszic Stanisław, Przestrogi dla Polski z teraźnieyszych związkow z praw natury wypadające przez Pisarza "Uwag nad życiem Jana Zamoyskiego, Dnia 4 Stycznia 1790, p. I - II.

90 "rząd wolny ma te istotę, że nie iedna osoba, ale Naród cały iest kraiu Dziedzicem. Ten prawie powszechnie na trzy stany dzieli się: Wieyski, Mieyski i Szlachecki. Ten Naród albo we wszystkich trzech stanach, albo w dwóch, albo w iednym z tych stanie, zwierzchnią Narodową władzę umieszcza". NN, Zbiór pism... Ósme pismo..., p. 9.

${ }^{91}$ Ibidem, p. 18.
} 
The political assumptions of Hugo Kołłątaj expressed in the "Letters of an Anonymous Writer" have a particular nature. They expressed a project to transfer townspeople into a co-governing state, represented in the Townsmen's Chamber, and setting up a joint lesser nobles and bourgeoisie sovereign. Kołłątaj, a supporter of a far-reaching social revolution, appealed: "Poles! I challenge you to finally become a nation and a truly free one!" 92

The translator of the bitter satirical "Catechism" inquires: "Who holds the legislative and executive power in the Republic?" And he obtains the following answer: "the King, the Senate and the knights, three states but one lesser nobleman. (...)It is a secret never to be conceived by reason that the Republic, having only one noble state for its government, did three states thereof, in such a wonderful way, and moreover, from one person of the king it has also created a complete state". ${ }^{93}$ Another question is: "After all, this can be seen that all the Polish Government Majesty is only the Republic of lesser Nobles?" And the answer: "It is obvious that in the Polish Nation, he who is not a Gentleman, may not even be human. $P$. [Question] Can the natural and property laws be altered by the Constitution of the Polish Government? O. [Answer] Where it comes to the dignity of the Nobility Estate in Poland, all such simple and insignificant laws as natural and property laws must give way." 94 In further part of the Catechism, the author tries to prove that particular honours of the Noble State are freedom and equality: "As lesser nobles in Poland are humans, some of them are rich, some poor, some are learned and some incompetent, some wise and others foolish. Well, they have the fundamental privilege of their Constitution that despite these distinctions of Providence, they are all equal, and as soon as a Pole is a lesser noble no feature of poor, or silly can be used thereto, as he has the holy equality of rights, which raises him over everything what Providence partly offers to humans"; the Dietines are a particular expression of this equality. ${ }^{95}$

\footnotetext{
92 “Polacy! Ośmielcie się, aby raz być narodem a narodem prawdziwie wolnym!”. Kołłątaj Hugo, Do prześwietnej Deputacji, In: Listy Anonima i Prawo polityczne narodu polskiego. Eds. Leśnodorski Bogusław, Wereszycka Helena, Vol. 1. Warszawa 1954.

${ }^{93}$ Król, Senat i Rycerstwo, trzy stany a jeden Szlachcic. (...) To tajemnica nigdy nie poięta rozumem, że Rzeczpospolita nie maiąc tylko ieden Stan Szlachecki do swojego Rządu, przecież z tego stanu zrobiła trzy stany, tak cudownym sposobem, iako i to, że z iednei Króla poiedynczey osoby, ma także ieden stan zupełny”. Katechizm o tajemnicach rządu polskiego, jaki był około Roku 1735 napisany przez JP. Sterne w ięzyku Angielskim, potym przełożony po Francuzku, a teraz nakoniec po Polsku, w Samborze, w Drukarni Jego Cesarsko-Królewsko Apostolskiej Mości, Roku 1790, dnia 10 Stycznia, p. 3-4.

${ }^{94}$ Wszakże z tego daie się widzieć, że cały Maiestat Rządu Polskiego iest tylko Rzecząpospolitą Szlachecką?", i odpowiedź: "To iest iawna pewność, że w Narodzie Polskim kto nie iest Szlachcicem, nie może być nawet człowiekiem. Pytanie: Jakże, czyliż Prawa natury i własności mogą się odmieniać przez Konstytucją Rządu Polskiego? Odpowiedź: Gdzie idzie o powagę Stanu Szlacheckiego w Polszcze, tam wszystkie takie proste i drobne prawa, iako Prawa natury i własności ustępować muszą"Ibidem, p. 5.

95 “Szlachta w Polszce ponieważ są ludźmi, są iedni bogaci i ubodzy, uczeni i nieumieiętni, rozumni i głupi. Otóż maią naygłównieyszy przywiley swoyei Konstytucyi, że mimo te rozróżnienia Opatrzności, są sobie wszyscy równi, i jak prędko w Polsczcze iest kto szlachcic, iuż do niego nie
} 
The peasant-farmer in Poland is not a human, he "has only qualities of soul and body, but his person is not a human, he is the Nobleman's own thing, who being an omnipotent Lord can sell or buy him, use him to his advantage." 96 A town resident is " $a$ being between the human or else the lesser noble and the non-human or else a peasant", "substantia incompleta". He lives like a gentleman, "the latter bows thereto, when in need to borrow money," but he does not have "all the powers which adorn human nature" because the law does not allow it: the law forbids him to be an abbot or bishop of a diocese, or an army officer, he may not cultivate the land, "in short, a townsman born in the Republic belongs to no state nor is he a citizen." 97

The author of another Catechism is kinder and treats his educational mission more seriously, thus sketching the political ideal, "So, do the people constitute the law?"Yes. In the Nation whose people are free, they enact the law, to which they subdue voluntarily and without coercion, "by which it differs from the people subordinated to an autocrat. Freedom means the ways which" the man grabs to become happy without harming anybody else. "Freedom has a natural dimension, it is the state of nature, citizenship, as well as a political dimension:" the status of the nation, which enacts the law itself on its own either by a common vote by the people themselves or by agreeing thereto by their representatives who express their will". ${ }^{98}$ The author defines the duties of citizens, including the political activity, "the obligation to work and hire oneself to the interest of the home country". However, the community is made up of three classes; lesser nobles, burghers, and farmers; the first state "was granted by the superior sovereignty this title to reward the merits in the service for the community, to reward talents and virtues". Townspeople are very needed and useful for the industry and work, whereas farmers "defend the States, feed and clothe all the other inhabitants (...) are the source of all the good and happiness of the nation and contribute to the power of each country." Both the lower classes are more useful for the nation, hence the need to foster them, "encourage them without having them in contempt, sweeten their hardships, declare great respect and gratitude, consider them friends and brothers", a nobleman, who despised them, would deserve a reprimand. "Such a conduct would mean his scarcity

\footnotetext{
należy ani ubóstwo, ani głupstwo, ale święta równość Prawa, wynosi go nad to wszystko, co Opatrzność po części rozdaie ludziom”. Ibidem, p. 14-15.

96 "ma tylko przymioty duszy i ciała, ale zaś osoba iego nie iest człowiekiem, ale rzeczą własną Szlachcica, który będąc Panem iedynowładnym chłopa, może go przedawać i kupować, obracać na swój pożytek". Ibidem, p. 5-6.

${ }^{97}$ pośrzedniczącym iestestwem między człowiekiem Szlachcicem, a nie człowiekiem chłopem”, "substantia incompleta". Żyje jak szlachcic, szlachcic "kłania mu się, potrzebując pieniędzy pożyczyć", lecz nie ma "wszystkich władz ozdabiających naturę człowieka", ponieważ prawo mu przeszkadza: prawo zakazuje mu być opatem zakonnym i biskupem diecezji, oficerem, nie może uprawiać roli, "słowem urodzenie Mieszczanina w Rzeczypospolitey nie ma ani stanu, ani iest w rzędzie obywatelstwa". Ibidem, p. 6-7.

98 "stan Narodu tego, który sam sobie prawa przepisuie, iuż to przez okrzyknienie powszechne samego ludu, iuż to przez zgodzenie się na to iego reprezentantów, którzy wyrażają iego wolę". Katechizm Narodowy w Warszawie, 1791, W Drukarni uprzywileiow. Michała Grolla, Księgarza Nadwormego J.K. Mci., p. 5-6.
} 
of enlightenment, his shortage of morality and politics (...), but unfortunately there still remains a great amount of unpunished superstition". 99

Supporters of far-reaching social reforms criticized the half-hearted parliamentary solutions, such as the ennoblement programme of townspeople proposed in autumn 1790. On the pages of an anonymous controversial brochure, which was attributed to Franciszek Salezy Jezierski, it was alleged that in this way the nobility wants to deprive the bourgeois class of its finest individuals and drag them insidiously to its side. ${ }^{100}$

As mentioned, the demands associated with the estate of peasants had a very limited character. They were an expression of the physiocratic doctrine, whose assumptions were contrasted with the uncertain legal position of the peasantry in Poland. An exception was Józef Pawlikowski, whose emancipatory writing "On Polish subjects" had a nearly revolutionary character. ${ }^{101}$ Appeals addressed to the King and the Parliament took the form of a call to the king to prove to be the father of "all" and make everybody without exception happy under his dominion. ${ }^{102}$ The arguments originated rather from the ecclesiastical doctrine or the ancient history, however "The light in Europe slowly expanding to Poland, had a difficulty in finding its access to the dispersed Polish lesser nobility, whereas all its way to the Peasants Estate was obstructed." 103 The opponents of radical action took the voice, "unenlightened people do not know what freedom means, and which decent freedom is vested in each state." 104 Many voices commonly realized a danger in the French example: "the hacks want to vest human equality and the sentence on freedom in the town, intoxicated by the French circumstances. This prejudice is false or rather the French plague moved into the heads of Polish writers; towns! do not believe this". ${ }^{105}$

\footnotetext{
${ }^{99}$ Obie niższe klasy są pożyteczniejsze dla Narodu, stąd wynika potrzeba sprzyjania im, "zachęcania ich, niegardzenia nimi, słodzenia trudów, oświadczania im największego uszanowania i wdzięczności, uważania ich iak przyjaciół i braci”, szlachcic, który by nimi gardził, wart by nagany. "Ten postępek ukazałby w nim niedostatek oświecenia, niedostatek moralności i polityki (...), lecz nieszczęściem wielka moc jeszcze pozostaie przesądów bez upodlenia”. Ibidem, p. 9-13. ${ }^{100}$ NN [F.S. Jezierski], Głos na prędce do stanu miejskiego, Warszawa 1790. Comp. GrześkowiakKrwawicz, Anna. 2000a. O formę rzadu..., p. 177-179.

${ }^{101}$ NN [Pawlikowski, Józef], O poddanych polskich, Roku 1788. Comp. also Rostworowski, Emanuel. 1963. Myśli polityczne Józefa Pawlikowskiego In: Legendy i fakty XVIII w. Rostworowski Emanuel (ed.). Warszawa: Państwowe Wydawnictwo Naukowe, p. 196-264.

${ }^{102}$ NN, Głos poddaństwa do Stanów Sejmujących, n.p., n.d.

103 "Światło w Europie powoli rozszerzające się z trudnością do Polski znalazło wstęp do rozproszonej szlachty, a wcale zatamowaną miało drogę do stanu wiejskiego". NN, Uwagi o chłopach, w Warszawie, w Drukarni uprzywilejowanej Michała Grölla, Księgarza Nadwornego J.K.Mci, in edition of Woliński Janusz, Michalski Jerzy, Rostworowski Emanuel. 1955. Materiały do Dziejów Sejmu Czteroletniego, Vol. 1, Wrocław: Zakład Narodowy im. Ossolińskich, Wydawnictwo Polskiej Akademii Nauk, p. 104.

104 “nie zna lud nieoświecony, co to wolność znaczy, jak każdemu stanowi w towarzystwie inna wolność przyzwoita". Ibidem, p. 106.

105 “chcą w miasta wrazić pismaki równość człowieka i zdanie o wolności, trafunkiem francuskim upojeni. Fałszywe to jest uprzedzenie, a bardziej zaraza francuska przeniesła się do głów polskich pisarzów; nie wierzcież temu, miasta”. Jezierski Jacek, Wszyscy błądzą. Rozmowa Pana z
} 
In the "Historical and Political Diary" (Pamiętnik Historyczno-Polityczny), this difficult issue is raised relatively less frequently and in a rather balanced way. ${ }^{106}$ The peasant issue very easily became an instrument of demagogic republican conservative narrative which would notoriously accuse the King and the reformist camp of plans for the peasantry emancipation or their incitement. ${ }^{107}$

Characteristically, after the adoption of the constitution and in the course of struggle for its retention, even at a time when the fate of the constitution was doomed, in view of the allegations of Stanisław Szczęsny Potocki, Marshal Małachowski defends the King against the charges of incitement of the peasantry and the middle class, "the thoughts of the King have always recognized the priority and superiority of the Nobility over the Burghers and Peasants; His Majesty makes no secret of this, however, that he wishes and thinks the thing needed is to improve the Urban State and agriculture more than the situation remained of the Parliament of $1786 " .{ }^{108}$

\subsection{3 'The Nation' in the Parliamentary Debate}

There is no doubt that the parliamentary plenum is the main forum in which the exclusive authority of the nobility, the Knights state and the Senators state to take up legislative actions is emphasized, which, at the same time, is just a kind of mystification, as this assumption was practically never challenged. In the first half of the eighteenth century, such opinions as the demands by Antoni Potocki "to create a state of townspeople equal to the lesser nobles" 109 were sporadic at the Parliament. Andrzej Zamoyski, the author of the draft of the Codification of Court Laws, spoke more emphatically in his famous speech at the 1764 Convocation. However, even though the journalism of the era of the Great Parliament opened to a larger extent to promoting a broader understanding of the nation, the parliamentary debate had much more conservative overtones.

Rolnikiem. Obaj z błędu wychodzą, W Warszawie u P. Dufour, konsyliarza nadwor. drukarza J.K.Mości i Rzplitej, dyrektora drukarni Korpusu Kadetów, 1790, in edition of Woliński Janusz, Michalski Jerzy, Rostworowski Emanuel. 1955. Materiały do Dziejów Sejmu Czteroletniego, Vol. 1, Wrocław" Zakład Narodowy im. Ossolińskich, Wydawnictwo Polskiej Akademii Nauk, p. 297.

${ }^{106}$ Homola-Dzikowska Irena. 1960. Pamiętnik..., p. 205-208. Comp. in particular: Myśli względem dopełnienia wolności i pomyślności narodowej przez Sejm niniejszy konstytucyjny, Pamiętnik Historyczno-Polityczny, 1791 I, p. 371-374.

${ }^{107}$ Michalski Jerzy. 1952. Propaganda konserwatywna w walce z reformą w początkach panowania Stanisława Augusta, Przeglad Historyczny, 43 (3-4), p. 560-561.

108 “myśli Krolewskie były zawsze uznające pierwszość i wyższość Szlachty nad Mieszczan i Chłopów; z tym się jednak Król JMść nie tai, że życzy i myśli rzeczą potrzebną ulepszyć Stan Mieyski i rolniczy nad sytuacyą która iest zostawiona po Seymie 1786". Copy of letter of JW. Małachowski to JW. Szczęsny Potocki Mar. G.Konf. Kor., de 5 Xbris 1792, AGAD, AKP, Pudło (box) 90, k. 692.

${ }^{109}$ Bieniarzówna Janina. 1952. Projekty reform magnackich w połowie XVIII w., Przegląd Historyczny, 42: 317. 
The nobles, as representatives of the Nation were elected to make the laws, including the specific ones, which was announced by the appointment of the Government Deputation with the task to draw up the "Bill for the New Form of Government". Shortly before finalizing the work, the townspeople representation started to act by submitting memoranda that even in their softened version were considered by the king to be too far-fetched. At the session on the 15 th of December 1789, castellan Jacek Jezierski appeared with an unusually sharp criticism of city delegates, whose activities he compared to a revolt against the fixed arrangement of social relations. ${ }^{110}$ Jan Dekert and other authors of the manifesto found it reasonable to keep the softened version and courageously stand up to the hetman "party of zealots". Krystyna Zienkowska argues that the King himself was opposed to the introduction of the townspeople issue on the agenda of the Parliament (nor did he like the introduction to the Memorial of city delegates referring in his opinion to French revolutionary literature), while Ignacy Potocki acted in a completely different way, introducing a revolutionary passage into the first edition of the "Rules...": "of the important duties of the nation to secure and bring up the freedom, property and equality of every citizen, derive the following rights and authority appropriate to the nation". ${ }^{111}$ Finally, the disputed fragment was prematurely "denounced" by deputy Suchodolski, who also alleged that the draft was not an agreed upon work of the entire deputation but, as a matter of fact, of one man. Under the influence of Suchodolski's speech, the term "nation" was deleted from all parts of the bill and replaced by the terms of "State of Lesser Nobility", "Republic", whereas "every citizen" was turned into "every resident". Thus, the task of the Republic was to guarantee the freedom and equality to the state of lesser nobles. ${ }^{12}$ Similarly, "the Draft to the Form of Government" turned out to be too republican. It spoke about sovereignty of the nation but did not refer the nation directly to the nobility, rather using it as an open notion, not quite defined. The Potockis' republicanism became widely too suspected and a similar situation took place as in the case of the "Rules ..." during the discussion on the cardinal laws in September 1790, the word nation was deleted and replaced with the term "Republic" and the conservative deputies further demanded to supplement it to state: "The Republic made up by lesser nobles". ${ }^{113}$

\footnotetext{
${ }^{110}$ Mowa JW. Jacka Jezierskiego na sejmie dnia 15 grudnia 1789 roku powiedziana, n.p. [Warszawa], n.d. In response appeared: Bezstronne uwagi nad mową JW. Jezierskiego... mianą na sejmie dnia 15 grudnia 1789 przeciwko mieszczanom J. Baudouina de Courtenay, Warszawa, Drukarnia M. Grölla, 1790. Jezierski then tried to accuse the author before the Court Marshal, and then called in parliament for legal action. Comp. Szczepaniec Józef. 1991. Sejm Wielki..., p. $168-170$.

${ }^{111} \mathrm{Z}$ istotnych powinności, które ma naród, zabezpieczenia i wychowania wolności, własności i równości każdego obywatela wypływają następujące prawa i władza narodowi właściwa". Printed amended proposal: AGAD, Archiwum Sejmu Czteroletniego, sygn. 13, k. 66. Comp. Zienkowska Krystyna. 1976. Stawetni i urodzeni. Ruch polityczny mieszczaństwa w dobie Sejmu Czteroletniego, Warszawa: Państwowe Wydawnictwo Naukowe, p. 103-106.

${ }^{112}$ Zienkowska Krystyna. 1976. Stawetni..., p. 111.

113 "Rzeczpospolita z stanu szlacheckiego złożona". AGAD, ASCZ, sygn. 9, k. 159. Cf. also Zienkowska Krystyna. 1976. Stawetni..., p. 117-119.
} 
The King remained neutral, not taking a voice at this session. Moreover, it was a deliberate policy of preparation for the consecutive phases of the discussion on the cardinal laws that were to apply to the royal prerogatives. Potocki lost this battle as well. $^{114}$

At the same time, the representative dimension of the deputies' parliamentary function in the context of the mandate entrusted with them by the local Dietines was generally regarded by them as very serious, as confirmed by discussions on the prorogation (extension) of the Parliamentary session (e.g. the discussion in September 1790, whether to "ask the nation" through the universal manifestos for the permission to extend the session) and the deputies' doubts about the legality of the regulations of Parliament carried out contrary to the Parliamentary instructions. The King pointed out in his voice of the 24th September, 1790: "Nobody respects the Rights of the Nation more, nor is anybody more convinced than I that the legislative power is not for life, thus it should return to its source i.e. the nation electing its Representatives". 115

On almost every occasion, the deputies were ready for a corresponding argument regarding the position of lesser nobility - an example can be the session No CCL of 20 April 1790, ${ }^{116}$ when, in connection with the planned census and vetting of farms, in fact, problems having nothing in common with politics, a discussion arose, whether "Christians" should be further divided into three classes, separate for the lesser nobility, townspeople and peasants; or whether lesser nobles should be included at all, as they are not recruited to the army nor do they pay a poll tax. Characteristically, a deputy of Pińsk, Butrymowicz added that "this obligation is not provided by any law as in itself that would be contrary to the Republican Spirit". Member Niemcewicz notes in response that every man belongs to the people and one should not be afraid to place lesser nobility in an appropriate column, as "woe be to the government that funds itself on inhumanity and terror. Let each citizen, influencing the government be just, let justice be equal to every state - then everyone will be attached to their own country, loving their natal land" and then he asks to return to substantive issues. ${ }^{117}$

All voices of the parliamentary debate are full of indications that these disputes were led by the "nation". In the parliamentary states the King pointed to the fact that

\footnotetext{
${ }^{114}$ Janeczek Zdzisław. 2007. Idea wolności w mowach i pismach Ignacego Potockiego. In: Sporyo państwo $w$ dobie nowożytnej: między racja stanu a partykularyzmem, Anusik Zbigniew (ed.), Łódź: Wydawnictwo Uniwersytetu Łódzkiego, p. 201-214.

115 “nikt nie poważa więcey Prawa Narodu y nie iest bardziey przeświadczony nade mnie, że Moc Prawodawcza nie dożywotnia, koleynie wracać się powinna do źrzódła swego, to iest do obierającego swych Reprezentantów Narodu". Głos J Kr. Mci Na Sessyi Seymowey dnia 24 Września 1790 Ru miany, AGAD, AKP, sygn. 207, k. 1047 (540).

${ }^{116}$ Dziennik Czynności Seymu Głównego Ordynaryinego Warszawskiego, pod związkiem Konfederacyi Oboyga Narodów agituiącego się 1790, Sessya CCL, Dnia 20 Kwietnia we Wtorek. 117 “biada takim rządom, które się funduią na nieludzkości i postrachu. Niech każdy Obywatel w Rząd wpływający będzie sprawiedliwym, niech równy każdemu stanowi wymiar sprawiedliwości oddawany będzie, w ten czas każdego przywiązanego do swego Kraiu swoią kochającego Oyczyznę zobaczemy". Ibidem.
} 
he was "within the National Jurisdiction", the "Enlightened Nation."118 The laws written by the Parliament are the laws of the Nation, ${ }^{119}$ the will of the Nation "shed into our mouths and our laws"120; and perhaps even more, what the constitutional Deputation does, "will flow from the will of the Commonwealth". ${ }^{121}$

Finally, the next stage of debate is an issue that appeared during the deliberations in early 1791, along with the adoption of the work on the law on regional assemblies (Dietines). Here, besides the theme of the rights of military officers in active service to parliamentary mandates, particularly vivid emotions were induced by the matter of deprivation of the rights of the non-property nobility failing to pay the due amount of tax. The repeated argument "in favour of" this solution consisted in the susceptibility of poor nobility to any pathologies associated with the occurrence of clientelism. The invoked counterarguments, on the other hand, focused on the injustice - the once obtained ennoblement for the "knight opus", for the blood shed for the country, whilst when contemporary economic relations and usury led to the impoverishment of this layer, it is proposed to withdraw the rights of the nonproperty nobility. ${ }^{122}$ The division of nobility so strongly emphasising its unity was feared as was the strengthening of the position of the aristocracy. "Not the rich, but the virtuous are the honour of the Country", said Józef Olizar. ${ }^{123}$ Also, the voices in that debate concerned with military rights recalled the roots of the nobility, the risks of isolating the military corps, as in a Republican Government the army could not be considered ministerial. ${ }^{124}$ On the other hand, it is necessary to note the voices in support of the withdrawal of rights of non-possessionists. Members saw this as the only way to free themselves from the magnates and clientelism. "There are three things which are the scariest for the Republic: the King having too much of a vantage, a powerful neighbour and an overbearing citizen. The law protects us from the first; the army covers the second, but the third would have remained, if parliamentary freedom was allowed for the non-possessionists" as member Boreyko

\footnotetext{
${ }^{118}$ Głos Jego Kr. Mości na Sessyi Seymowey dnia 20. Lipca 1789. miany, AGAD, AKP, sygn. 207, k. 813 (443).

${ }^{119}$ Prince Czartoryski in the debate on how to perform tasks by deputations from the Chamber asks: "Kto ieźli można tak myśleć, że to, coby postanowiły Osoby od Seymu, y z pośrzód niego obrane, nie byłoby Prawodactwem Seymowym, że go cały Seym nie stanowi, toby równie powiedzieć można, że Prawa, które Seym pisze, nie są Prawami Narodu, bo ich sam cały Naród nie pisze". Sessya 36, 17 Lutego 1791 r, AGAD, ASCz, sygn. 19, k. 571.

${ }^{120}$ [Wola Narodu] “przelana do ust i prawa naszego”Głos Jaśnie Wielmożnego Marcina Leżeńskiego posła Bracławskiego Względem Proiektu dokączenia Opisów Seymikowych Dnia 18. Lutego Roku 1791. W Izbie Seymowey miany, Sessya 37 dnia 19 Lutego 1791 R., AGAD, ASCz, sygn. 19, k. 634.

121 "to będzie wypływało z woli Rzplitej”. Such reasoning Suchodolski, Castellan of Radom assigns to antagonists.Sessya 37 dnia 19 Lutego 1791 R., AGAD, ASCz, sygn. 19, k. 629od.

${ }^{122}$ Comp. Voice of JW. Suchodolski, Sesja 33 Dnia 11 Lutego 1791 R., AGAD, ASCz, sygn. 19, k. 481, and other voices in this session, especially Józef Kalasanty Olizar, Volyn member, k. 491- 492od.

123 "Nie bogaci, lecz cnotliwi stanowią honor Kraju”. Ibidem, voice of Olizar, k. 491od.

${ }^{124}$ Sessya 34 z 14 lutego 1791, Sessya 35 dnia 15 lutego 1791 R., AGAD, ASCz, sygn. 19, k. $530-579$ od.
} 
perorated. ${ }^{125}$ Adam Lityński rightly points out the specific paradox of the Polish political scene - saving democracy by limiting political rights. ${ }^{126}$

At the same time this deadlock in parliamentary work made the members aware of how inefficient the parliamentary procedure was to allow the deliberations over individual provisions of the law on regional assemblies to be delayed for several days, which was to be counteracted by the project proposed by member of Krakow Sołtyk, which entrusted legislative binding transactions to the constitutional deputation elected by the Parliament. ${ }^{127}$ Members wished, however, to deliberate on the regulation of assemblies, i.e. those that they were directly related to, in pleno.

The issue of towns appeared in the second half of 1789. An analysis of royal speeches allows to find references to the generosity of Warsaw and special royal favours to Krakow. In his speech of the 15th of December, 1789, the King expressed himself in the following way: "it is not only my opinion that the grandeur of the Knights State deserves being granted freedoms and liberties, but it is also in its [Knights Estate's] interest." 128 This confirms the previous notes that the reform measures were to be limited to an "improvement", "raising" of the status, extending the rights of townspeople, but absolutely not to contribute to their equality. The words of the king recorded in the spring of 1791 are of a bit more progressive character, i.e. already in the course of works on the Law on towns where the king stressed his obligations towards the towns and cities, the duty to defend "the rights and privileges of people of any condition." 129 In another comprehensive speech of the 14th of April, 1791, he cited the example of the Danish nobility that, reserving all the rights for themselves and denying them to other estates, "went towards the fullest government of absolutism." 130 According to the King, the extension of the rights was to change the attitude of the townspeople, who would be interested in defending their freedom "together" with the nobility [in case of an external emergency]. He was of the opinion that it was insufficient for townspeople to be entitled to send

\footnotetext{
125 “Trzy są rzeczy dla Rzeczypospolitey naystrasznieysze: Król nadto przewagi maiący, sąsiad potężny i przemagaiący obywatel. Od pierwszego zabezpiecza nas prawo; od drugiego zasłania wojsko, ale zostałby się trzeci, gdyby wolność sejmikowania, nieposesjonatom dozwolona była". Voices from 28 January 1791., cited in Gazeta Narodowa i Obca, Nr X z 2 lutego 1791, p. 1.

${ }^{126}$ Lityński Adam. 1999. Sejmik jako instytucja demokracji szlacheckiej 1764-1793. Tradycje mity-nowości -utopie. In: Parlamentaryzm i prawodawstwo przez wieki: prace dedykowane prof. Stanisławowi Płazie w siedemdziesiątą rocznicę urodzin, Malec, Jerzy, Uruszczak Wacław (ed.), Kraków: Wydawnictwo Uniwersytetu Jagiellońskiego, p. 76, p. 75-86.

${ }^{127}$ Comp. for example Głos Jaśnie Wielmożnego Imci Pana Piusa Kicińskiego, Posła Ziemi Liwskiey, Na Sessyi Seymowey Dnia 17 lutego 1791 R., AGAD, ASCz, sygn. 19, k. 583 - 584v. and the other voices.

128 "nie tylko iest zdaniem moim, że przystoi wspaniałości Stanu Rycerskiego nadawać im wolności y swobody, ale że to iest y Interessem jego". Głos JKMci na Sessyi Seymowey dnia 15. Grudnia 1789. miany, AGAD, AKP, sygn. 207, k. 897 (460).

${ }^{129}$ Głos Jgo Kr. Mości na Sessyi Seymowey dnia 6. Kwietnia miany [1791], AGAD, AKP, sygn. 207, k. 1193 (612).

${ }^{130}$ Głos J. K. Mci na Sessyi Seymowey dnia 14. Kwietnia 1791 miany, AGAD, AKP, sygn. 207, k. 1198.
} 
a deputation, without the right to vote, "without freedom of speech, until asked,"131 which eventually would be included in the provisions of the future Constitution. The final reform would cover slightly more than $30 \%$ of the townspeople living in free royal cities. Undoubtedly, the very process of selection of deputies to departmental assemblies, construction of desiderations, listening to the reports from the selection of the plenipotentiary all may be seen as a form of political mobilization of the middle class. ${ }^{132}$ However, the implementation of the demands of the bourgeois movement should be assessed as extremely restrained.

The peasantry-related topic is rarely present in the parliamentary discussion. A similar tone to that used by free media was applied by Adam Wawrzeniec Rzewuski, who thus spoke in the debate over the starosties: "I say freedom requires too pure a light, too noble a soul, to honor with it our not-enlightened farmers". ${ }^{133}$

In the May discussions, doubts regarding the legitimacy of the Great Parliament to adopt the constitution returned. It was emphasized that, since the legislature was with the people, it could only be realized by local assemblies (Dietines), with the Members of Parliament being mere interpreters of the will. "The will of the Nation does not come from the will of the members, but from the entire composition of citizens having the right of choice of the Representatives of Law who in the name of their tenure at the members' choosing, give the power to do express their will in the legislation." 134 A member from Oszmiana, Chomiński, thus lamented by proposing implementation of a despotic government: "The Parliament has already become the Master of your will, and You the Nation, giving power to the representatives having it so far, have already lost it" by introducing succession "despite the majority number of Instructors in favour of the Election". ${ }^{135}$ These voices, already recorded in a heated discussion on the 3rd of May will soon echo in numerous writings critical of the constitution. Anna Grześkowiak-Krwawicz indicates that it was one of the most

\footnotetext{
${ }^{131}$ Ibidem, k. 1201 (616).

${ }^{132}$ Bałtruszajtys Grażyna. 1996. "Zgromadzenia ludu miejskiego" według projektów i ustaw Sejmu Czteroletniego. In: Parlament, prawo, ludzie. Studia ofiarowane Profesorowi Juliuszowi Bardachowi w sześćdziesięciolecie pracy twórczej, Iwanicka Katarzyna, Skowronek Maria, Stembrowicz Kazimierz (ed.), Warszawa: Wydawnictwo Sejmowe, p. 47-54.

133 "wolność mówię zbyt czystego wymaga światła, zbyt szlachetney duszy, aby się nią nie oświeceni rolnicy nasi zaszczycać już mogli”. Adama Wawrzeńca Rzewuskiego kasztelana witebskiego Głos w Stanach Rzeczypospolitey Zgromadzonych dnia 31 Października 1791, AGAD SD III 1.

134 “Wola Narodu nie pochodzi od woli Posłuiących, ale od całego składu Obywatelów do wyboru Reprezentantów Prawa maiących, którzy w Imieniu swym na Poselskie urzędowanie wybierając, moc czynienia w przepisach woli swey daią." Głos JP Posła Wileńskiego Korsaka, for: NN [Siarczyński], Dzień Trzeci Maja Roku 1791, w Warszawie, Nakładem Drukarni M. Grolla, Księg. JKM, p. 94.

135 “już Seym stał się Panem Twojey woli, a Ty Narodzie, nadawczą moc Reprezentantom maiąc dotychczas, iuż ją straciłeś", [wprowadzając sukcesję] "mimo większość liczby Instrukcyow za Elekcją” JP Chomiński, poseł Oszmiański, for: NN [Siarczyński], Dzień Trzeci Maja..., p. 147.
} 
serious allegations against the constitution, accusations of breaching one of the fundamental political principles. ${ }^{136}$

\subsection{4 'The Nation' in Constitutional Acts}

As indicated above, the term "nation" did not appear in earlier constitutional acts. In the "Rules for improvement of the form of government" of December 1789 inspired by Kołłątaj and prepared by Ignacy Potocki, the concept of the nation was deleted and replaced by the concepts of "lesser nobility estate", and the "Republic", "who entrusted the proper authorities and rights". A key duty of the state in the final version of the act was to ensure freedom to the nobles, preservation of their equality, retrenchment of ownership of each inhabitant and extension of governmental protection to "all in general". ${ }^{137}$

Eventually, a similar step was made in September 1790 when the cardinal laws were approved and finally published in January 1791. Also here there is absence of a broader reference or modern understanding of the term "nation". What is meant is the establishment of laws by the nobility "for the nation", "and those [laws] that people only owe obedience to". It is solely the nobility that remain the political nation - "free speech at regional assemblies" for every nobleman "is most solemnly protected". "Free speech", expressed in speech or in writing, shall however be entitled to "every citizen". ${ }^{138}$

Finally, the Constitution, adopted on the 3rd of May, contained many paradoxes as far as the issue of "nation" is concerned. As the enacting entity, the monarch was indicated together with the Parliament by these words: "Stanistaw August, by the grace of God and the will of the Nation, Polish King, Grand Duke of Lithuania, Russia, Prussia, Mazovia, Zemajtija, Kyiv, Volyn, Podole, Podlasie, Livonia, Smolensk, Siverskyi and Chernihovsk together with the confederated states in a dual number, representing the Polish nation." It is clear that, in fact, without the consent of the states, the King could not introduce any constitutional regulation, as it was only the lesser nobility that had the legislative power. Subsequently, the Constitution used the words "the fate of us all". The concept of "the nation" appeared wider in two regulations - in the Rousseau-like art. V: "All the authority in a human society takes its origin in the will of the nation. So to keep the whole States, civil liberties and social order equally important forever, three authorities shall constitute the government of the Polish nation, and always will by force of this law, that is: the legislative authority in the assembled estates, the supreme executive authority of the King and the Guard, and the judicial authority in jurisdictions to that end instituted or to be instituted," and art. XI, the National Armed Force: "The nation owes to itself its own defence against an attack and preservation of its integrity. Therefore,

\footnotetext{
${ }^{136}$ Grześkowiak-Krwawicz, Anna. 2012. Czy rewolucja może być legalna? 3 maja w oczach współczesnych, Warszawa: Wydawnictwo DiGA, p. 68-70.

${ }^{137}$ Zasady do poprawy formy rządu, Volumina Legum, t. IX, p. 157-159.

${ }^{138}$ Prawa kardynalne niewzruszone, Volumina Legum, t. IX, p. 203-204.
} 
all citizens are defenders of national integrity and liberties. The Army is nothing else, but only a defensive and decent force extracted from the overall strength of the nation. The nation owes its army a reward and esteem for the exclusive devotion to its defence. The army owes the nation protection of borders and maintenance of common peace, in short, it is to be its strongest shield". ${ }^{139}$ Interpreters of both regulations come to an agreeable conclusion that the word nation referred to in art. V had a limited scope, and practically related only to the nobility authorized by a number of laws to participate in the executive, legislative and judicial powers, whereas art. XI already imposed such an obligation on all citizens, however, of course, the Constitution did not construct the notion of a "citizen of the Republic." It was merely a foretaste of the bourgeois revolution but in practice the duty to defend was to refer both to the estate of lesser nobility and peasants, which was later proved by the military action against Russia, both in the war for the defence of the Constitution in 1792, as well as in the Tadeusz Kościuszko Insurrection in 1794.

In summary, in Poland the principle of sovereignty was formulated in such a way that all the authority originates with the will of the people, strictly to emphasize that the function of representation of the people in enacting the law was only fulfilled by a "free nation", that is such that by virtue of tradition and the past should "prevail in public life." It can be assumed that the 3rd of May constitution uses the terms "free nation" not in the context of national sovereignty but rather to refer to its political representation. This concept also appears in the about-constitutional laws, to precisely define the nobility as a state playing the role of a representative of the nation.

The said nation was still divided into classes, which was reflected in the very structure of the Constitution. Its extensive art. II entitled "Gentry-landlords" left no illusions - profound changes in social issues were missing in the Government Act. Nor did art. III, dedicated to the townspeople, realize the demands expressed by the publicist writings. On the other hand, special attention is deserved to the fact that in parallel to a slight improvement of the situation of the townspeople, it ended up in withdrawing the rights of the non-possessionist nobility. A consistent interpretation is that these measures are likely to open the way to changes in the system of constitutional monarchy based on the bourgeoisie. Also, Article III, dedicated to the townspeople did not realize the demands expressed by the literature. At the same time, however, it should be noted that, in accordance with article VI of the constitution, "the deputies elected by the Dietines will be recognized in the legislation and

\footnotetext{
${ }^{139}$ Art. V: “wszelka władza społeczności ludzkiej początek swój bierze z woli narodu. Aby więc całość państw, wolność obywatelską i porządek społeczności w równej wadze na zawsze zostawały, trzy władze rząd narodu polskiego składać powinny i z woli prawa niniejszego na zawsze składać będą, to jest: władza prawodawcza w Stanach zgromadzonych, władza najwyższa wykonawcza w królu i Straży, i władza sądownicza w jurysdykcjach, na ten koniec ustanowionych, lub ustanowić się mających" and Art. XI: Siła zbrojna narodowa: "Naród winien jest sobie samemu obronę od napaści i dla przestrzegania całości swojej. Wszyscy przeto obywatele są obrońcami całości i swobód narodowych. Wojsko nic innego nie jest, tylko wyciągniętą siłą obronną i porządną z ogólnej siły narodu. Naród winien wojsku swemu nadgrodę i poważanie za to, iż się poświęca jedynie dla jego obrony. Wojsko winno narodowi strzeżenie granic i spokojności powszechnej, słowem winno być jego najsilniejszą tarczą".
} 
the general nation's needs according to this Constitution as the representative of the whole nation in whom the common trust will be vested". ${ }^{140}$ The article mentioned the entire nation, not only the nobility. Deputies were supposed to represent the needs of the entire nation, also the peasants and burghers who, although did not elect these Members of Parliament, place in them their hope for the realization of their interests, since deputies were persons of social (public) trust.

The Constitution in fact lifted the instructions although the law passed a month earlier on Dietines ${ }^{141}$ - after rejecting the different proposals twice - purposely preserved the binding nature of instructions. The king was also subjected to the will of the people, in accordance with the broadly discussed (see further below) article VII of the highest executive authority entrusted with the king only after ensuring "the free nation power of establishment of its laws" and "the power to guard over all executive authorities and elect officials to magistracies". ${ }^{142}$

The article of the constitution devoted to the bourgeoisie only declared that the law of the royal towns be part of the constitution, "as the law of the free Polish nobility ensuring new, genuine and effective force for the security of their liberties and the integrity of common Fatherland." ("jako prawo wolnej szlachcie polskiej, dla bezpieczeństwa ich swobód $i$ całości wspólnej Ojczyzny nowa, prawdziwa $i$ skuteczna dajace sitę"). Even the consecutive article devoted to the peasantry was much broader, although in fact it represents only physiocratic praise of the rural state and its responsibilities. The real significance could only be seen in the commitment to draw up detailed contracts with the peasants and the announcement of freedom for the immigrant population. ${ }^{143}$ There came a political revolution, neither social nor economic one.

\subsection{The Monarch as a Sovereign}

\subsubsection{Introduction}

As noted already in the introduction, no thesis of the exclusive sovereignty of the monarch was ever raised in Poland, because this would have never been approved. Such an understanding of the role of the monarch was established naturally through

\footnotetext{
140 "posłowie na sejmikach obrani w prawodawstwie i ogólnych narodu potrzebach podług niniejszej konstytucji uważani być mają jako reprezentanci całego narodu, będąc składem ufności powszechnej”. Volumina Legum, t. IX, p. 222.

${ }^{141}$ Seymiki (Prawo o Seymikach), Actum in Curia Regia Varsaviensi Die Vigesima Octava Mensis Maij, Anno Domini Millesimo Septingentessimo Nonagesimo Primo, Zbiór Ustaw Seymowych w Warszawie; also: Volumina Legum, Wydawnictwo Komisyi Prawniczej Akademii Umiejętności w Krakowie, t. IX, Kraków 1889, p. 289-241.

${ }^{142}$ Zagwarantowanie "wolnemu narodowi władzy praw jego stanowienia" i "mocy baczności nad wszelką wykonawczą władzą, oraz wybierania urzędników do magistratur".

${ }^{143}$ Leśnodorski Bogusław. 1951. Dzieło Sejmu Czteroletniego (1788-1792). Studium historycznoprawne, Wrocław: Wydaw. Zakładu Narodowego im. Ossolińskich, p. 226-230.
} 
the elective experience. Moreover, it is easy to notice the ultimate exclusion of the monarch from the scope of discussion on the shape of law-giving powers. And yet, Kołłątaj precisely concluded: "never did the nation honestly think that the republican government depended on reducing the king's prerogatives, but on permanent actions of the people representing the will of the nation and exercising it". ${ }^{144}$ In this sense, a proof of maturity of the nation was a parliamentary resolution of September 1790 which restored the monarch's right to grant offices, withdrawn in $1775 .{ }^{145}$ Until that time, however, an almost phobic attitude towards monarchs had dominated, as they were constantly accused of absolutist tendencies. Also Stanisław August Poniatowski would frequently be an object of such a propaganda in the earlier period of his reign. ${ }^{146}$ At the same time, it was reluctantly admitted that the King was a stabilizing element of the political system. ${ }^{147}$ Nonetheless, it was agreed that the King was the embodiment of majesty, the carrier of solemnity and dignity, a representative in external relations. ${ }^{148}$

Hence, the question of the monarch's position was, by far, the most vividly discussed problem of sovereignty and aroused the strongest emotions, in particular the way of his appointment, that is, the decision whether to continue the election, or rather introduce the hereditary throne. The talk on this issue would burst almost suddenly, often on the occasion of subsidiary questions. In terms of parliamentary discussions, one can clearly distinguish several major stages: discussion on the "Rules for improvement of the form of government" in December 1789, followed by the ongoing debates in autumn 1790 on a draft of the cardinal laws and then on the proclamation to the Nation. Ultimately, the case was settled surprisingly, and contrary to numerous Dietines instructions, by enacting the May Constitution introducing the election by a dynasty and appointing the Saxon Elector Frederick Augustus to the throne after the death of King Stanisław August Poniatowski.

\subsubsection{The Monarch in the Debate of Public Media}

As indicated earlier, the monarch was no longer perceived as a legislative authority acting on his own. Michał Wielhorski in the already cited dissertation on freedom took a radical position: the King does not even have the role of an estate, he is not even one of the pillars of "independence" - as supported by the fact that even during the interregnum the State will be able to function. ${ }^{149}$ The Kings became exclusively

\footnotetext{
144 “nigdy zaś rzetelnie nie pomyślał naród, iż rząd republikantski nie zależy na odjęciu prerogatyw królowi, lecz na nieprzestannym działaniu osób reprezentujących naród i wolę jego wykonywających". [Kołłataj Hugo],1954. Listy Anonima i Prawo polityczne narodu polskiego. Eds. Leśnodorski Bogusław, Wereszycka Helena, Warszawa, Vol. 1.p. 265.

${ }^{145}$ Volumina Legum, t. IX, p. 183.

${ }^{146}$ Michalski Jerzy. 1952. Propaganda..., p. 536-562.

${ }^{147}$ Grześkowiak-Krwawicz, Anna. 2003. Czy król..., p. 472-473.

${ }^{148}$ Ibidem, p. 474-475.

${ }^{149}$ Michał Wielhorski,,op.cit., p. 44-45.
} 
the "first officials of the Republic". ${ }^{150}$ The author of the anonymous "Thoughts on improving the Forms of Government" emphasized the subordination of the King to the law, concluding that "all power, all law-giving rights that earlier served the only authority of Polish Kings, today is the attribute of the Knights'state. The King holds the priority everywhere, he presides everywhere, but he decides nowhere."151

The main stage of discussions in the free media on the role of the monarch was the dispute between the protagonists and antagonists of king's succession. ${ }^{152}$ One of the most famous protagonists was an activist of the Republican camp - a hetman, Seweryn Rzewuski. Amazingly, in his key pamphlet, ${ }^{153}$ he did not use classic arguments of traditional, historical postulates against hereditary monarchy, but rather referred to current world events. It is the irony of fate that this conservative Sarmatian, a significant politician, a rich magnate opposing any social reforms, with sympathy invoked the revolutionary events in Franceand the United States assuming that the system devoid of a King was better than the hereditary monarchy. It shall be noted, however, that the voices in favour of abolition of the monarchy in the system of government were very rare. ${ }^{154}$

In the debate about the succession, the issue of freedom was also strongly emphasized. It was widely believed that the election "granted us a lot of freedom", ${ }^{155}$ although the opponents cited historical arguments also in favour of the fact that at the times of hereditary kings, the Polish State was free, and the election contributed to as much freedom as anarchy. ${ }^{156}$ The essential argument against the election, the "pupil of freedom", was the problem of anarchy during the interregnum.

Finally, the topic of the debate should be concluded with a strong accent. How does the King of Poland hold the throne? - as inquired by the author of the aforementioned Catechism. "A King chosen in a free election is conceived in the womb of the Republic, behind the veil of nobility's freedom, owing to a powerful neighbouring State (...) The King is himself a complete estate, although in nature, he is only a single individual." "What is his importance in governing the Nation? During his election, the King means everything, after he takes the Throne, he does not mean much." "How is it that he means a lot during his election?" "The Nation, unwilling

\footnotetext{
${ }^{150}$ Ibidem, p. 226.

151 "wszelka władza, całe prawodawstwo, które przedtym iednowładnym Królom Polskim służyło, dziś iest w Rycerskim Stanie. Król wszędzie trzyma pierwszeństwo, wszędzie prezyduie, lecz nie decyduie nigdzie”. NN, Myśli... Myśl Ósma. Myśl względem..., p. 28.

${ }^{152}$ These issues have repeatedly been analyzed in Polish literature. It is necessary to recall the work of Zielińska Zofia. 1991. "O sukcesyi tronu w Polszcze" 1787-1790. Warszawa: Wydawnictwo Naukowe PWN, recently also some significant voices of the debate recalled the aforementioned Rafał Lis.

${ }^{153}$ Seweryna Rzewuskiego hetmana polnego koronnego o sukcessyi tronu w Polszcze rzecz krótka, n.p., n.d.

[Drezno 1789]. Walicki, Andrzej. 2000. Idea narodu..., p. 33-34. The title of brochure also served Z. Zielińska for the title of the aforesaid paper.

${ }^{154}$ Grześkowiak-Krwawicz, Anna. 2003. Czy król..., p. 483.

${ }^{155}$ Myśl z okazji “Uwag nad życiem Jana Zamoyskiego, n.p.. [Warszawa], 1788, p. 43.

${ }^{156}$ Grześkowiak-Krwawicz, Anna. 2004. O starożytnej wolności..., p. 43-45, 50-52.
} 
to do anything for the public good, decides to take over all domestic needs from the King in Pacta Conventa; so at that time the King means as much as should be the task of the entire Nation." After coming to power, he does not mean much, "because the aristocracy, using the nobility differentiation, do not allow him to do anything. The rule over the military, the municipal courts, supervision of the Treasury, even the safety of the Majesty, all is transferred into the hands of Ministers, all that is left to the king's office is "convening Parliament, appointing officers, signing the fairs." 157

\subsubsection{The Monarch in the Parliamentary Debate}

As mentioned before, Stanisław August Poniatowski played a prominent role during parliamentary discussions. His parliamentary speeches were characterized by acceptance of the customary rules of debate - which was supposed to be polite and erudite, however, the content had evolved: from his cautious statements from 1788 to 1789 to progressive ideas expressed in 1791 .

As a rule, the King would use the parliamentary forum to emphasize his position of subordination to the Nation ("those obligations which, among others, the Nation placed upon me when they elected me to reign over them", ${ }_{158}$ "I recognise it is an honour to wear this Crown, which by your will was placed upon my head", ${ }^{159}$ "my Office", 160 "appointed for the Throne by the Nation"161), and his absolute reluctance to interfere with the powers and free discretion of the states, declared at least formally, which was supposed to be illustrated by the repeatedly quoted King's expression: "The King with the Nation, the Nation with the King". A subsequent passage

\footnotetext{
157 "Król wolną wybrany Elekcyą, poczyna się w żywocie Rzeczypospolitey, pod zasłoną wolności szlacheckiey, za sprawą iakiego Sąsiedzkiego Mocarstwa (...) Król iest stanem zupełnym, choć iest w naturze tylko poiedynczą osobą". W zarządzeniu Narodu Król co znaczy? Król przy swoiey Elekcyi znaczy wszystko, po obięciu Panowania nie wiele". "jakże to wiele znaczy przy swoiei Elekcyi?" "Naród niechcąc nic czynić dla dobra publicznego, wszystkie potrzeby krajowe wyzbacza zastąpić Królowi w Paktach Konwentach; więc Król w ten czas to znaczy, co powinno być dziełem całego Narodu". Po objęciu władzy znaczy niewiele, "bo możnowładztwo Panów, używając rozróżnienia Szlachty, nie dopuszcza mu nic czynić. Rząd woyska, Sądy Miast, dozór Skarbu, beśpieczeństwo nawet Majestatu, wszystko przeniesione iest w ręce Ministrów, władzy królewskiej pozostało "zwoływanie Seymu, rozdawanie Urzędów, podpisywanie Jarmarków". Katechizm o tajemnicach..., p. 11-12.

158 "te obowiązki, które przy innych włożył na mnie Naród, gdy mi nad sobą Królować kazał". Mowa Jego Królewskiej Mości na Sessyi Seymowey dnia 9. Stycznia 1789. Roku miana, AGAD, AKP, sygn. 207, k. 807 (415).

159 “znam chlubę nosić tę Koronę, którą Wola Wasza na Skronie moie włożyła”. Mowa Jego Kr. Mości na Sessyi Seymowey dnia 26. Marca 1789 Rku miana, AGAD, AKP, sygn. 207, k. 829 (426).

${ }^{160}$ Głos Jgo Kr. Mci na Sessyi Seymowey dnia 1go kwietnia 1791 Roku. Miany, AGAD, AKP, sygn. 207, k. 1187 (609).

161 "wezwany do Tronu wolą Narodu". Głos JKr. Mci na Sessyi Seymowey dnia 22 września 1791 r. miany, AGAD, AKP, sygn. 207, k. 1267 (649).
} 
is also of great importance: "I noticed long ago the advantage that a King reigning over a free Nation has over those Kings who govern in absolutist States, because the King of a free Nation, together with the representatives of free co-citizens, has the daily opportunity to strengthen his determination and have his mind enlightened through the comments made by those who, by engaging in parliamentary discussions with the King, exercise the sovereignty and enact the legislation for the Nation, while an absolutist Parliament has to determine everything on its own", "I am nourished by the light of my fellow deputies of the Parliament", says the King. ${ }^{162}$ Similarly, after the constitution had been adopted, he continued to emphasize: "When the duties of ruling were placed upon me in the Pacta Conventa, I decided to understand always that the King of Poland shall never act without the Parliament, only shall he act, according to the will of the Parliament, which represents the Nation and its will', and this was a particular feature of the doubled, constitutional Parliament. ${ }^{163}$

As noted, it was very easy for the Parliament to become a place to discuss the duties of the King and the manner of his appointment. The parliamentary sessions of September 1790 were a typical phase of this discourse. In the discussion over an unfinished article concerned with the nobility, who "were free to create offices and appoint officers to hold them", a Volhynian member of the Parliament, Świętosławski, demanded that an amendment be made to say that the nobility are "free to appoint Kings". The Lithuanian Marshal pointed out in his response that, in his opinion, such an amendment did not protect the interests of members as it was probably the members' intention to exclude the rule of a dynasty, and this option assumed either the election of a family or the election of a King. As regards Świętosławski's suggestion, it was requested that a proclamation be sent to the Nation; in response, member Przyłuski, the castellan of Brzeziny opposed, arguing that a nation who recognized the need for conscription and military taxes, "would not hesitate to inform their representatives through instructions if it found the succession to the Throne to be its common good". Member Niemcewicz promptly upheld his prosuccession position arguing that since the law and the Polish people's virtues prohibit it, a succession king would not seize "the Treasury, the Army and the Tribunals". The example of England was supposed to prove that although the throne there was hereditary but the rulers did not seek omnipotence, "the freedom in France increases but nobody in France suggests the dynasty be disposed of'(sic!). Niemcewicz pro-

\footnotetext{
162 “dawno zważałem awantaż Króla panującego w wolnym Narodzie nad temi Królami, którzy rządy absolutne sprawuią, ponieważ Król wolnego Narodu wspólnie z Reprezentantami wolnych Współ-Obywatelów ma codzienną sposobność zasilania determinacyi swoiei, y oświecania swych myśli przez podawane uwagi od tych, którzy seimuiąc wspólnie z Królem, samowładność y prawodawstwo Narodu sprawuią, a absolutny sejm sam na siebie brać musi wszelkie determinacye", "zasilam się światłem współseymuiących". Głos Jego Kr. Mości na Sessyi Seymowey dnia 10. Maia 1791. Roku miany, AGAD, AKP, sygn. 207, k. 1219 (625).

163 "gdy Mi przepisywane były Królowania powinności w Paktach Konwentach, tak one poiąłem, y w tym nieodzownym zostaię rozumieniu, że Król polski, nic czynić bez Seymu nie powinien, tylko z wolą Seymu, Naród y Wolą Yego reprezentującego". Głos JKr. Mci na Sessyi Seymowey dnia 22 września 1791 r. miany, AGAD, AKP, sygn. 207, k. 1267 (649).
} 
posed to issue a proclamation, describing the calamities that result from an interregnum. Lastly, member Suchodolski took the floor, presenting Hungary, Czech, Denmark and Sweden as examples of misery brought about by hereditary thrones. Finally, Suchodolski emphasized that since the objectives of the adopted Rules (Zasady) referred "to an improvement of the form of government," that meant that they were about improvement, not about creating a new system. To conclude, while the king was still alive, one should not think about his successor. ${ }^{164}$ His supporters included member Rzyszczewski, who claimed that the proclamation would suggest the Saxon dynasty to the Polish throne, whereas the Elector had no son, only a daughter, which would cause further problems. He also explicitly said that "during interregnums, the lesser nobility has always sought to increase their freedoms and expand the boundaries of their privileges, but when Succession is introduced, this will be unthinkable and these privileges will be more and more suppressed." ("w czasie bezkrólewiów zawsze przyczyniała sonie wolności Szlachta, i tego Przywileju rozszerzała granice, a gdy stanie Sukcessya już o rozszerzeniu onych myśleć nie będzie wolno, kiedy coraz to bardziey ścieśniane będa”). In response, a member from Podolia, Morski, presented some predictable arguments, and the bishop from Livonia, Kossakowski, concluded that "the Nation's liberty rests upon the free election of the king" ("wolność Narodu zasadza się na wolney Tronu Elekcyi"), that this freedom should not be overthrown during the confederated Parliament, and the discussion on the superiority of election over succession should be left to historians. He also called upon the 1607 law, folio 1596, which states: "He, who dares to suggest succession to the throne shall be tried in court pro hoste Patria \& perduelli." ("ten pro hoste Patria \& perduelli będzie sadzony, ktoby się odważyt proponować Sukcessya Tronu"). ${ }^{165}$

In the debate on the day when the Constitution was adopted, the monarch could not explicitly say that the bill was written under his guidance, and that he had a direct influence on its final shape consulted with the Potockis' reforming wing through the secretary Scipione Piattoli. ${ }^{166}$ The King emphasized, having been somewhat distanced from it: "the draft has been born out of this what was shown to me, and what is in accord with the will of many parliamentarians" ${ }^{167}$ This distance is

\footnotetext{
${ }^{164}$ Dziennik Czynności Seymu Głównego Ordynaryinego Warszawskiego, pod związkiem Konfederacyi Oboyga Narodów agituiącego się 1790, Sessya CCCXIII, Dnia 16. Września, we Czwartek.

${ }^{165}$ Dziennik Czynności Seymu Głównego Ordynaryinego Warszawskiego, pod związkiem Konfederacyi Oboyga Narodów agituiącego się 1790, Sessya CCCXIV, Dnia 17. Września, w Piątek.

${ }^{166}$ This is unfortunately not the place to discuss the process of creating the final text of the Constitution and mutual chases between the King and Ignacy Potocki. Comp. Dihm Jan. 1930: Przygotowanie Konstytucji 3-go Maja ważnym etapem w urzeczywistnieniu idei niepodległości, Pamiętnik V Powszechnego Zjazdu Historyków Polskich w Warszawie 28 listopada do 4 grudnia 1930 r. T. I Referaty, Tyszkowski Kazimierz (ed.), Lwów: nakładem Polskiego Towarzystwa Historycznego, p. 386-398.

167 "urodził się z tego projekt, który Mi był pokazany, a który iuż iest zgodny z Wolą wielu Seymuiących". Głos JKr. Mości na Sessyi Seymowey Dnia 3go Maja 1791. Roku miany z okazji proiektowaney nowey Formy Rządu, AGAD, APK, sygn. 207, k. 1209 (620).
} 
further expressed, just in case, in the following words which undoubtedly referred to the succession: "in the same bill, I found such things, or else one point, which I am myself reluctant to touch and rather should not following the Will of the Nation, therefore, I declare that I had doubts in this one point". ${ }^{168}$ After the bill had been read, Stanisław August Poniatowski requested to be released from the relevant prohibition in pacta conventa. The pacta were read and the discussion continued. In its course, the reform camp members spoke out, arguing for the succession and trying to palliate the expressed theatrically, yet justified worries of the king. The speeches were, in fact, directed not to Poniatowski but to the hetman's conservative camp. ${ }^{169}$ The representative of the latter, member Chomiński from Oszmiana, argued that such a large group of antagonists of the Constitution means that the nation does not free the king from the oath at pacta conventa. ${ }^{170}$ This issue, as mentioned, was further developed in political journalism on the 3rd of May.

Let us also not forget about another political scene, where an equally emotional discussion on the election was under way. During the meetings of Dietines of November 1790, where, at the request of the King, expressed in the manifesto of the Parliament Marshals, the election proposals related to the Elector of Saxony as an heir to the throne in the Vivente rege procedure with the king still living were decided. 55 regional Dietines accepted the nomination suggested, while 36 of them were in favour of maintaining the elective monarchy, and only nine - allowed for hereditary monarchy. ${ }^{171}$

Later voices in the debate generally accept changes made in the constitution. Characteristic is the voice of Tadeusz Kościałkowski, member of Wiłkomierz, raised in September 1791: "King, it was a futile word, and not a thing important and holy, several Kings shared the executive authority among themselves, and the Nobility was not more free and raised against the Ruler, not that it hated him, but since that was a need of the mightier nobility, the mightier argued with the Throne until they achieved what they demanded." ${ }^{172}$

\footnotetext{
168 "w tym samym proiekcie znalazłem rzeczy takie, czyli punkt ieden, którego Ja Sam przez się tykać się niechcę, y nie powinienem chyba za Wolą Narodu, dlatego oświadczam, iż w tym iednym punkcie zastanowiłem się." Ibidem, k. [chart] 1210.

${ }^{169}$ NN [Siarczyński], Dzień Trzeci Maja..., as example voice of deputy Zakrzewski, p. 74.

${ }^{170}$ Ibidem, p. 147-148.

${ }^{171}$ Łukowski Jerzy. 2010. Szlachta i monarchia: refleksje nad zmaganiami inter majestatem ac libertatem. In: Rozkwit i upadek I Rzeczypospolitej, Butterwick Richard (ed.), Warszawa: Bellona, p. 167.

172 “Król, było to czcze słowo, a nie rzecz ważna i święta, kilkunastu Królików dzieliło władzę Jego wykonawczą po między siebie, Szlachta z tym wszystkim nie była wolnieyszą, powstawała na swego prawego Rządzcę, nie iżby go nienawidziała, lecz, że tak było potrzeba możnieyszym, a możnieysi póty się z Tronem kłócili, póki tego, czego żądali, nieosiągnęli.”. Głos Jaśnie Wielmożnego Imci Pana Tadeusza z Zyndramów Kościałkowskiego, starosty czotyrskiego, posła Wiłkomirskiego, Orderu Ś. Stanisława Kawalera, Na Sessyi Seymowey dnia 20 Miesiąca Września, 1791. Roku Miany, AGAD, ASCz, sygn. 22, k. [chart] 55v.
} 


\subsubsection{The Monarch in the Constitutional Acts}

"Rules for improvement of the form of government" (Zasady do poprawy formy rzadu) from December 1789 almost ignored the issues of the legal status of the King. Defining, above all, the powers of the nobility, the stipulated principles dictated the election of the King of the Roman Catholic religion. The Rules entrusted to him "the highest, uniform and general supervision”(,naywyższy, iednostayny $i$ ogólny dozór"), and exercising of rights. The King and his guard was to serve as "the primary government protection" (art. 6to). ${ }^{173}$

Also "Inviolable cardinal laws" from September 1790, finally published in January 1791 dictated that the King was Catholic by birth "or vocation". The King "freely chosen" remains the prerogative of the "Republic" in a state of nobility. The King was also required to preserve the rule "neminem captivabimus nisi iure victum". ${ }^{174}$ No compromise was reached on the manner of succession to the throne (the original version of the rights provided for the election of the Dynasty); due to parliamentary disputes and the inability to reach a compromise, it was decided to move this dilemma to be taken care of at the level of local assemblies. They were also to decide whether to present to the Elector of Saxony, Frederick Augustus Wettin, the proposal to take over the Polish throne after the death of King Stanisław August. ${ }^{175}$

Wider regulations were brought about as late as with the Government Act (Ustawa Rządowa). The King was devoted only to Article VII of the Constitution of the 3rd of May ("The King, the executive power"). He was entrusted - however "in the council," i.e. the Guardian of Rights - the highest executive authority, which should limit itself to "the observation of the laws and carrying them out" and should be active wherever the law permits and even requires enforcement. "The executive power will not be able to enact or interpret laws" ("Władza wykonawcza nie będzie mogła praw stanowić ani ttumaczyc'"), impose taxes, raise public debts, alter the budget, enact war, peace and other treaties, but merely lead temporary negotiations.

The throne was henceforth to be elective in dynasties. This decision was dictated by "the experienced disasters of interregnum", thus protecting the fate of each of the residents, shutting down the influence of foreign powers and their ambitions to the throne, calling the "unanimous cultivation of national liberty." The issue of inheritance of the throne, as mentioned, was settled in favour of the Elector of Saxony, followed by his daughter and son-in law; significantly, the diplomatic activity in order to consult the person concerned was carried out very inconsistently.

The person of the King was to be "holy and safe from everything." "Doing nothing by himself, cannot respond to the nation in relation to any matter". The King "shall not be an autocrat, but the father and head of the nation, and as such he is

\footnotetext{
${ }^{173}$ Zasady do poprawy formy rządu, Volumina Legum, t. IX, p. 157-159.

${ }^{174}$ Prawa kardynalne niewzruszone, Volumina Legum, t. IX, p. 202-203.

${ }^{175}$ Zielińska Zofia. 1991. “O sukcesyi...”, p. 137-221.
} 
recognized and declared by the law and this constitution". ${ }^{176}$ Legal acts and judgments should be issued in the name of the King, he was entitled to the right of pardon, to supremacy over the army, appointment of ministers, officials, senators and bishops. ${ }^{177}$ Ministers, Guard members participated in such powers of the King as convening of the Parliament, exercising of the prerogative of pardon and the right of legislative initiative, but the opinion of the King finally prevailed. Hence, it was being spoken of a creation of "something like the King's institution within the Guard", whereas Bogusław Leśnodorski even considered a possible analogy with the presidential system of the United States of America. ${ }^{178}$ Royal acts required ministerial countersigning and if any minister refused and the King insisted on a decision, the Parliament was expected to be an instance of conciliation.

\section{Summary}

The Stanisław Poniatowski era of reform was to constitute merely the beginning of a revolution, announcing a deeper planned social and economic transformation. It was a "gentle revolution" held without a profound deconstruction of the status quo. Even its opponents were aware that the projects were not overly progressive, though this was not an obstacle for them to invoke the bloody example of France as a precaution to the public. Stanisław Szczęsny Potocki realistically and prophetically evaluated the plans of the King already post factum, in 1792, "and as for the French [way, reform], I have no doubt that the King is not interested in disseminating it, but there is a middle way which they want to keep it seems, however in this middle way neither security, nor an end can be found". ${ }^{179}$ The King naturally distanced himself from the events of the French Revolution. The correspondence of the monarch with

\footnotetext{
176 "Nic sam przez siebie nie czyniący, za nic w odpowiedzi narodowi być nie może. Nie samowładcą, ale ojcem i głową narodu być powinien i tym go prawo i konstytucja niniejsza być uznaje i deklaruje”. Volumina Legum, t. IX, p. 222-223.

${ }^{177}$ Council composed of: primate, the Minister of Police, the Seals, War, Treasury and Foreign Affairs. The right to participate in meetings without voting rights also have adult heirs to the throne and the Marshal of parliament.

${ }^{178}$ Leśnodorski Bogusław. 1951. Dzieło Sejmu Czteroletniego (1788-1792). Studium historycznoprawne, Wrocław: Wydaw. Zakładu Narodowego im. Ossolińskich, p. 309, 319 (certain analogy saw a researcher indicated e.g. in the institution's message to the nation rendering in parliament). Similarity, however, it belies the fact that the introduction of countersignature and lack of proper royal prerogatives (except for acts of supreme command during the war). There are studies showing that changes in the form of work within the Guards came almost at the last moment - in the draft submitted to the King by Piattoli on April 29, after the comment of Stanisław Kostka Potocki was ultimately ruled that the Guard did not vote, and that the king takes the decision. However, they were effective only after the countersignature.Comp. Rostworowski Emanuel. 1966. Ostatni król, Geneza i upadek Konstytucji 3 Maja, Warszawa: Wiedza Powszechna, p. 214-216, 224-225, $228-230$.

179 “co zaś do francuszczyzny, nie wątpię, że króla nie iest interesem rozszerzać Ich naukę, lecz iest śrzednia droga, którey się chcą trzymać iak się zdaie, lecz w tey śrzedniey drodze ani
} 
Feliks Oraczewski, an envoy in Paris, perpetuated a negative image of the revolution in the King's perspective. ${ }^{180}$

It can be assumed that, contrary to numerous antagonists, it would not have come to a strong consolidation of royal power at the expense of the noble parliamentary representation. It is difficult to imagine that in a country with entrenched "republican" tradition the pursuit of monarchical absolutism could be accepted. This occurred on the Polish soil only with partitioners, neighbouring powers. The idea of a "middle way" - reformatory rather than revolutionary, also remained on the municipal agenda.

An important element of the "republican monarchy" was the key position of the Parliament. In none of the feudal countries did the Parliament "play such a polymorphous role as in Poland, nor was it as strongly associated with the history of the nation and the state or had such a great impact on the history. It [the Parliament] called itself the guardian of the rights of the Republic and its nobility. Its authority was derived from the nature of freedom and the sovereignty of their representatives, which allowed it to think of itself as being synonymous with the Republic and with freedom itself'. ${ }^{181}$

The analysed sources show that modern Western political doctrines were wellknown to protagonists of the era of the Great Parliament. At the same time, however, they were subject to a specific reinterpretation, and to some extent also served as a tool of petrification of the existing system. As Bogusław Leśnodorski rightly pointed out, "natural law", "sovereignty of the nation", "separation of powers" all these terms had a specific meaning for us (...). After all, they are not concepts and related phenomena that can be considered "beyond time" and beyond a given place. These are historical categories, with an undoubtedly variable content" 182 .

At the same time a certain myth-making role of the political thought of the First Republic should be noted. During the partitions "noble traditions gradually became general national traditions and the old Sarmatians were found synonymous with Poles. The traditional Polish idea of the "noble nation", and thus the idea of defending the noble freedom transformed into the principle of defence of national independence". ${ }^{183}$ Joachim Lelewel would announce soon that the principle of the noble nation's sovereignty was an embryonic form of the principle of the people's sovereignty. At the same time, however, according to the later theses of numerous

bezpieczeństwa, ani końca nie znajdzie". Copy of letter: JW. Marszałek Konfederacyi Generalney Koronney do JW. Pana Marszałka W.K. de 12 Xbris 1792, AGAD, AKP, pudło (box) 90, k. 694.

${ }^{180}$ Kocój Henryk. 1988. Misja Feliksa Oraczewskiego w Paryżu podczas Sejmu Wielkiego w świetle jego korespondencji ze Stanisławem Augustem Poniatowskim i Joachimem Chreptiowiczem. In: W dwusetną rocznicę wolnego Sejmu: ludzie - państwo - prawo czasów Sejmu Czteroletniego, Lityński Adam (ed.), Katowice: Prace Naukowe Uniwersytetu Śląskiego w Katowicach, p. 15-40.

${ }^{181}$ Olszewski Henryk. 1983. Funkcjonowanie sejmu w dawnej Rzeczypospolitej. Czasopismo Prawno-Historyczne, T. XXXV (1), p. 162.

${ }^{182}$ Leśnodorski Bogusław. 1951. Dzieło..., p. 411.

${ }^{183}$ Olszewski Henryk. 2001. Doktryna złotej wolności i spory o jej spuściznę. Państwo i Prawo, 60 (2), p. 6. 
political scientists, the freedom of the nobles contributed to the "misery" of liberalism in the nineteenth-century Poland - in Andrzej Walicki's opinion it was even an anti-individualistic phenomenon, with the doctrine and practice of such freedom constituting "more of a participation in the collective sovereignty than protection of individual rights". ${ }^{184}$

Finally, it is worth giving the floor to the author of the Catechism who underlined the fact that in Poland misfortunes rarely came from the nature - no earthquakes nor famine are known and the plagues are rare. Poland has its own misfortunes, "separate from other nations" - these are the Interregnum, Confederations, elections, the corruption in the elections, amnesties, and "by these arrangements of its Government, the Republic shall be so tortured and weakened", that it is enough to stand for "all the effects of a disastrous war." 185 These were extremely prophetic words as soon afterwards Poland lost its sovereignty for over 100 years and the Constitution of the 3rd of May, as well as further plans of the Great Parliament's deputies remained only a paper reform. One can only consider whether it could follow the same path as Britain, moving into the modern era of the rule of law without episodes of absolutist regime.

\section{Summary (Polish)}

W poszukiwaniu wątków suwerenności w debacie epoki Sejmu Wielkiego (17881792) poddano analizie kilka wybranych kategorii źródeł, które wyselekcjonowane zostały w założeniach poświęconego problemowi formowania się nowoczesnych konstytucji projektu badawczego ReConFort, którego ustaleń pierwszą odsłonę stanowi niniejsze studium. W zakresie obowiązujących źródeł prawa w przypadku polskim skupiono się na regulacjach Zasad do Formy Rządu, Prawach kardynalnych opublikowanych w styczniu 1791, Ustawie Rządowej oraz składających się obok niej na system Trzeciego Maja prawach o miastach (z kwietnia 1791) i o sejmikach (z marca 1791). Prześledzono także w ograniczonym jednak zakresie debatę parlamentarną, utrwaloną na łamach diariuszy sejmowych i dziennika czynności sejmu, jak również w postaci opublikowanych "mów", "przymówień", "głosów". Spośród źródeł o mniej czy wcale niejurydycznym charakterze badaniami objęto szeroko rozumiane media, przy czym polski przypadek oczywiście cechuje mniejsza obecność $\mathrm{w}$ dyskursie publicznym czasopism politycznych (w istocie rzeczy na to miano zasłużyć w pełni mógłby tylko Pamiętnik Polityczny y Historyczny Piotra Świtkowskiego), przy niebywale obfitej obecności wolnych druków, pamfletów, tworzących nieraz intelektualną dyskusję w przestrzeni publicznej (przeróżne odpowiedzi, przymówienia kierowane do konkretnych prac).

\footnotetext{
${ }^{184}$ Ibidem, p. 9.

${ }^{185}$ nieszczęścia "oddzielne od innych Narodów”, są nimi Bezkrólewia, Konfederacje, Elekcje, poparcie elekcji, amnestie, "temi układami swojego Rządu tak się zmorduie i osłabi Rzeczpospolita", że jej to wystarczy za "wszystkie skutki szkodliwej woyny". Katechizm o tajemnicach..., p. 22-23.
} 
Ograniczoną kwerendą objęto także źródła archiwalne w zakresie notatek i prywatnej korespondencji głównych protagonistów politycznych procesów (jak dotychczas Ignacego Potockiego, Kołłątaja, wybrane zespoły zachowanych akt dotyczących Stanisława Augusta). Otrzymane dotychczas wyniki trudno uznać za satysfakcjonujące i bez wątpienia ta kategoria źródeł wymaga bardziej pogłębionej analizy.

Kategoryzacja źródeł znalazła swe odzwierciedlenie w strukturze niniejszego opracowania. Zdecydowano się na wyróżnienie kilku płaszczyzn analizy. Po uwagach wstępnych zaprezentowano ustalenia w zakresie ogólnie pojmowanej teorii suwerenności $\mathrm{w}$ badanej dyskusji. Na uwagę zwraca fakt utożsamiania suwerenności z niezależnością wobec sąsiednich potęg oraz bezpieczeństwem wewnętrznym, co naturalnie jest pokłosiem działania państwa w nadzwyczajnych warunkach - w czasach po I rozbiorze Polskie, w okresie próby uwolnienia spod protektoratu Rosji w przejściowej, korzystnej sytuacji geopolitycznej. Podkreślono tu także długą polską tradycję "suwerenności prawa".

Kolejna obszerna część pracy poświęcona została pojęciu narodu i jego interpretacji w debacie. Piśmiennictwo temu poświęcone wyraźnie pozostaje pod wpływem innowacyjnych idei z zachodu i nie kwestionuje faktu, że "naród" jest suwerenem. Wykonywanie suwerennej władzy powierzono posłom skupionym w sejmie (tego przymiotu nie przypisywano wprost członkom senatu pochodzącym z mianowania, oczywiście zmiana nastąpiłaby, gdyby weszły w życie demokratyzujące nieco tę kwestię procedury wyboru senatorów, dokonywanego przez następców Stanisława Augusta spośród dwóch kandydatów). Nie można zapominać, że poważnie rozumiano węzeł między posłem a lokalną społecznością - poseł związany był formalnie instrukcjami, składał relacje $\mathrm{z}$ ustaleń sejmowych na sejmikach i to one ostatecznie zamknęły proces uchwalania konstytucji - sejmiki zebrane jesienią 1792 r. jako wyraz "woli narodu" w ogromnej przewadze dokonały zaprzysiężeń lub laudacji konstytucji. Niekwestionowalne pozostaje zarazem ograniczenie narodu politycznego wyłącznie do szlachty, choć na uwadze trzeba też mieć fakt jej znaczącego procentowego udziału w ogóle społeczeństwa (ok. 8\%), co dawało prawa wyborcze rzeszy wyborców liczniejszej niżniejednazdziewiętnastowiecznych konstytucji opartych na kryterium majątkowym. Debata publiczna nad poszerzeniem prawa reprezentacji obejmującym warstwę mieszczańską przyniosła ograniczone rezultaty. Posłowie znacznie ostrożniej niż publicyści podchodzili do kwestii, dopatrując się w działaniach ruchu mieszczańskiego i wydarzeniach "czarnej procesji" swoistego szantażu, grożenia rewolucją społeczną i "Francuszczyzną". Uchwalone ostatecznie prawo o miastach obowiązywało tylko w wolnych miastach królewskich, tj. nieco ponad 30\%, i upoważniało zaledwie do wyboru i kierowania do parlamentu plenipotentów z głosem doradczym w sprawach miejskich. Kwestia chłopska pojawiała się z rzadka $\mathrm{w}$ piśmiennictwie publicystycznym - jeszcze rzadziej w obradach sejmu.

Opracowanie zamyka część poświęcona monarsze. Choć polski porządek polityczny nie uprawnia do stawiania tezy o suwerennej władzy króla, mimo formuły uchwalenia konstytucji z woli królewskiej, to jednak nader istotne jest uzupełnienie obrazu o zagadnienie budzące ogromne emocje polityczne. Mowa o dyskusji nad 
następstwem tronu, w której obóz postępowy podważył kluczową zasadę wolności szlacheckiej, tj. elekcję króla. Przywołując w szczególności takie argumenty, jak anarchia bezkrólewi, próby obsadzenia zagranicznych książąt w drodze przekupstwa szlachty, protagoniści doprowadzili do utrwalenia kwestii w obszarze publicystyki. Są to problemy znakomicie już w literaturze przedmiotu opracowane, stąd celem autorki jest jedynie podkreślenie obecności tych zagadnień w szerzej pojmowanej dyskusji nad suwerennością. W debacie parlamentarnej nie odważono się w zasadzie na podniesienie tej kontrowersyjnej kwestii, samo zaś przyjęcie w Ustawie Rządowej regulacji elekcji dynastii, czyli w istocie sukcesji tronu, stanowiło w oczach "republikantów” jej grzech śmiertelny.

Przedłożone opracowanie stanowi wynik wstępnej części badań prowadzonych w ramach projektu ReConFort. Dalsza analiza koncentrować się będzie zagadnieniach zasady prymatu konstytucji oraz odpowiedzialności ministerialnej i urzędniczej jako przedmiotów dyskusji w przestrzeni publicznej.

Open Access This chapter is distributed under the terms of the Creative Commons Attribution 4.0 International License (http://creativecommons.org/licenses/by/4.0/), which permits use, duplication, adaptation, distribution and reproduction in any medium or format, as long as you give appropriate credit to the original author(s) and the source, a link is provided to the Creative Commons license and any changes made are indicated.

The images or other third party material in this chapter are included in the work's Creative Commons license, unless indicated otherwise in the credit line; if such material is not included in the work's Creative Commons license and the respective action is not permitted by statutory regulation, users will need to obtain permission from the license holder to duplicate, adapt or reproduce the material.

\section{References}

Bałtruszajtys, Grażyna. 1996. "Zgromadzenia ludu miejskiego" według projektów i ustaw Sejmu Czteroletniego. In Parlament, prawo, ludzie. Studia ofiarowane Profesorowi Juliuszowi Bardachowi w sześćdziesięciolecie pracy twórczej, ed. Katarzyna Iwanicka, Maria Skowronek, and Kazimierz Stembrowicz, 47-54. Warszawa: Wydawnictwo Sejmowe.

Bardach, Juliusz. 1983. Sejm dawnej Rzeczypospolitej jako najwyższy organ reprezentacyjny. Czasopismo Prawno-Historyczne XXXV(1): 134-147.

Bardach, Juliusz. 2002. Historia ustroju i prawa polskiego. Warszawa: Państwowe Wydaw. Naukowe.

Bieniarzówna, Janina. 1952. Projekty reform magnackich w połowie XVIII w. Przeglad Historyczny 42: 304-330.

Borkowska-Bagieńska, Ewa. 1992. Nowożytna myśl polityczna w Polsce 1740-1780, Studia z Dziejów Polskiej Myśli Politycznej, Vol. IV. Od reformy państwa szlacheckiego do myśli o nowoczesnym państwie, Toruń: 31-45

Borkowska-Bagieńska, Ewa. 2009. O świadomości prawnej szlachty w czasach stanisławowskich i potrzebie jej badania. Studia z dziejów państwa i prawa polskiego, XII: 151-158, Kraków-Lublin-Łódź.

Borucka-Arctowa, Maria. 1957. Prawo natury jako ideologia antyfeudalna. Warszawa: Państwowe Wydawnictwo Naukowe. 
Dihm, Jan. 1930. Przygotowanie Konstytucji 3-go Maja ważnym etapem w urzeczywistnieniu idei niepodległości. In Pamiętnik V Powszechnego Zjazdu Historyków Polskich w Warszawie 28 listopada do 4 grudnia 1930 r. T. I Referaty, ed. Kazimierz Tyszkowski, 386-398. Lwów: nakładem Polskiego Towarzystwa Historycznego.

Dziadzio, Andrzej. 2006. O konstytucji 3 maja 1791 roku na tle koncepcji ustrojowych Oświecenia. Państwo i społeczeństwo Rok VI, nr 4: p. 16 and f.

Dziadzio, Andrzej. 2010. Polnische Version des Rechtsstaates vom Ende des 18 Jahrhunderts (System des Verfassungsrechts 1791). In Parliaments: The law, the practice and the representations. From the Middle Ages to the Present Day, 117-123. Lisbon: Assembleia da República, Dezembro de.

Ekes, Janusz. 2001. Trójpodział władzy i zgoda wszystkich Naczelne zasady „ustroju mieszanego” w staropolskiej refleksji politycznej. Siedlce: Instytut Historii Akademii Podlaskiej.

Grześkowiak-Krwawicz, Anna. 1987. Polska myśl polityczna lat 1772-1792 o systemie władzy monarchii absolutnej. Kwartalnik Historyczny z. 3: 41-58.

Grześkowiak-Krwawicz, Anna. 1992. Za czy przeciw ustawie rządowej? Historia pewnej polemiki. Wiek Oświecenia, 8: Wokót Rewolucji Francuskiej i Sejmu Czteroletniego: 169-184.

Grześkowiak-Krwawicz, Anna. 2000a. O formę rzadu czy o rząd dusz? Publicystyka polityczna Sejmu Czteroletniego. Łódź: Instytut Badań Literackich Polskiej Akademii Nauk.

Grześkowiak-Krwawicz, Anna. 2000b. O recepcji umowy społecznej w Polsce w czasach stanisławowskich. Czasopismo Prawno-Historyczne LII(1-2): 109-125.

Grześkowiak-Krwawicz, Anna. 2003. Czy król jest potrzebny w republice? Polscy pisarze polityczni wieku XVIII o miejscu i roli monarchy w Rzeczypospolitej. Zarys problematyki. In Dwór a kraj między centrum a peryferiami władzy. Materiały konferencji naukowej zorganizowanej przez. Zamek Królewski na Wawelu Instytut Historii Uniwersytetu Jagiellońskiego, Instytut Historii Akademii Pedagogicznej w Krakowie w dniach 2-5 kwietnia 2001, ed. Skowron Ryszard, 467-486. Kraków: Zamek Królewski na Wawelu, Państwowe Zbiory Sztuki.

Grześkowiak-Krwawicz, Anna. 2004. O starożytnej wolności Polaków. Historia wolności polskiej w dyskusjach politycznych i historycznych wieku XVIII. In Teki Historyczne - Cahiers d'Histoire - Historical Papers, vol. XXIII, 34-53. Londyn: Polskie Towarzystwo Historyczne w Wielkiej Brytanii.

Grześkowiak-Krwawicz, Anna. 2006a. Staropolska koncepcja wolności i jej ewolucja w myśli politycznej XVIII w. Kwartalnik Historyczny, t. CXIII(1): 57-83.

Grześkowiak-Krwawicz, Anna. 2006b. Regina libertas. Wolność w polskiej myśli politycznej XVIII wieku. Gdańsk: słowo/obraz terytoria.

Grześkowiak-Krwawicz, Anna. 2010. Polskie poglądy na monarchie europejskie. In Rozkwit $i$ upadek I Rzeczypospolitej, ed. Richard Butterwick, 149-165. Warszawa: Bellona.

Grześkowiak-Krwawicz, Anna. 2012. Czy rewolucja może być legalna? 3 maja w oczach wspótczesnych. Warszawa: Wydawnictwo DiG.

Grzybowski, Konstanty. 1959. Teoria reprezentacji w Polsce epoki Odrodzenia. Warszawa: Państwowe Wydawnictwo Naukowe.

Homola-Dzikowska, Irena. 1960. Pamiętnik Historyczno-Polityczny Piotra Świtkowskiego 1782_ 1792. Kraków: Rozprawy i Studia - Uniwersytet Jagielloński.

Idebski, Zbigniew. 1958. Bodinus a Polska myśl polityczna. In Jan Bodin, Andegaweńczyk, Szesść ksiag o Rzeczypospolitej, ed. Zbigniew Izdebski. Warszawa: Państwowe Wydawnictwo Naukowe.

Janeczek, Zdzisław. 2007. Idea wolności w mowach i pismach Ignacego Potockiego. In Spory o państwo w dobie nowożytnej: między racja stanu a partykularyzmem, ed. Anusik Zbigniew, 201-214. Łódź: Wydawnictwo Uniwersytetu Łódzkiego.

Kasparek, Joseph -. Obst. 1980. The constitutions of Poland and of the United States. Kinship and genealogy. Miami: The American Institute of Polish Culture.

Kocój, Henryk. 1988. Misja Feliksa Oraczewskiego w Paryżu podczas Sejmu Wielkiego w świetle jego korespondencji ze Stanisławem Augustem Poniatowskim i Joachimem Chreptiowiczem. 
In Wdwusetna rocznicę wolnego Sejmu: ludzie - państwo - prawo czasów Sejmu Czteroletniego, ed. Adam Lityński, 15-40. Katowice: Prace Naukowe Uniwersytetu Śląskiego w Katowicach.

Krzywoszyński, Przemysław. 2007. Suwerenność w myśli szlachty polskiej. In Nad społeczeństwem staropolskim. Vol. 1 Kultura - instytucje - gospodarka w XVI - XVIII stuleciu, ed. Karol Łopatecki and Wojciech Walczak, 11-21. Białystok: Ośrodek badań Europy ŚrodkowoWschodniej Zakład Historii nowożytnej Instytut Historii Uniwersytet w Białymstoku.

Leśnodorski, Bogusław. 1951. Dzieło Sejmu Czteroletniego (1788-1792). Studium historycznoprawne. Wrocław: Wydaw. Zakładu Narodowego im. Ossolińskich.

Lis Rafał. 2012. Między Konstytucją 3 maja a Targowicą. Poglądy polskich republikantów w latach 1791-1793. Czasopismo Prawno-Historyczne LXIV (2): 161-191.

Lityński, Adam. 1985. O reformach sejmikowania 1764-1793. Czasopismo-Prawno-Historyczne XXXVII (2): 257-281.

Lityński, Adam. 1999. Sejmik jako instytucja demokracji szlacheckiej 1764-1793. Tradycje mity-nowości -utopie. In Parlamentaryzm i prawodawstwo przez wieki: prace dedykowane prof. Stanisławowi Płazie w siedemdziesiąta rocznicę urodzin, ed. Jerzy Malec and Wacław Uruszczak, 75-86. Kraków: Wydawnictwo Uniwersytetu Jagiellońskiego.

Łojek, Jerzy. 1988. Prasa dawnej Rzeczypospolitej. In Dzieje prasy polskiej, ed. Jerzy Łojek, Wiesław Władyka, and Jerzy Myśliński, 18-22. Warszawa: Interpress.

Łukowski, Jerzy. 2010. Szlachta i monarchia: refleksje nad zmaganiami inter majestatem ac libertatem. In Rozkwit i upadek I Rzeczypospolitej, ed. Richard Butterwick, 167-185. Warszawa: Bellona.

Maciejewski, Janusz. 1977. Pojęcie narodu w myśli republikanów 1767-1775. In Idee i koncepcje narodu w polskiej myśli politycznej czasów porozbiorowych, ed. Janusz Goćkowski and Andrzej Walicki, 21-41. Warszawa: Państwowe Wydaw. Naukowe.

Makiłła, Dariusz. 2010. Idea jedności a koncepcja rozdziału władz w teorii i praktyce ustrojowej Rzeczypospolitej na przełomie XVI - XVII w. In W kręgu nowożytnej i najnowszej historii ustroju Polski. Księga dedykowana Profesorowi Marianowi Kallasowi, ed. Sławomir Godek, Dariusz Makiłła, and Magdalena Wilczek-Karczewska, 1-20. Warszawa: InterLeones Halina Dyczkowska.

Michalski, Jerzy. 1952. Propaganda konserwatywna w walce $\mathrm{z}$ reformą w początkach panowania Stanisława Augusta. Przeglad Historyczny 43(3-4): 536-562.

Michalski, Jerzy. 1983. Z problematyki republikańskiego nurtu w polskiej reformatorskiej myśli politycznej w XVIII w. Kwartalnik Historyczny 90: 327-338.

Olszewski, Henryk. 1983. Funkcjonowanie sejmu w dawnej Rzeczypospolitej. Czasopismo Prawno-Historyczne T. XXXV (1): 149-162.

Olszewski, Henryk. 1985. Sejm konny. Rzecz o funkcjonowaniu ideologii demokracji szlacheckiej w dawnej Polsce. Czasopismo Prawno-Historyczne XXXVII: 225-242.

Olszewski, Henryk. 2001. Doktryna złotej wolności i spory o jej spuściznę. Państwo i Prawo 60(2): 3-17.

Pepłowski, Franciszek. 1961. Stownictwo i frazeologia polskiej publicystyki okresu oświecenia $i$ romantyzmu. Warszawa: Państwowy Instytut Wydawniczy.

Rostworowski, Emanuel. 1963. Myśli polityczne Józefa Pawlikowskiego In Legendy i fakty XVIII w, ed. Emanuel Rostworowski 196-264. Warszawa: Państwowe Wydawnictwo Naukowe.

Rostworowski, Emanuel. 1966. Ostatni król, Geneza i upadek Konstytucji 3 Maja. Warszawa: Wiedza Powszechna.

Rostworowski, Emmanuel. 1987. Ilu było w Rzeczypospolitej obywateli szlachty. Kwartalnik Historyczny 94(3): 3-58.

Szczepaniec, Józef. 1991. Sejm Wielki wobec zagadnień cenzury i wolności słowa In Antynomie Oświecenia. Tom specjalny w 200 rocznice Konstytucji 3 maja, Acta Universitatis Wratislaviensis, Prace Literackie XXXI, ed. Matuszewska Przemysława and Zakrzewski Bogdan, 155-184. Wrocław: Wydawnictwo Uniwersytetu Wrocławskiego.

Szczygielski, Wojciech. 1991. Konstytucja 3 Maja. In Konstytucja 3 Maja w tradycji i kulturze polskiej, ed. Alina Barszczewska-Krupa. Łódź: Wydawnictwo Łódzkie. 
Szczygielski, Wojciech. 1994. Referendum trzeciomajowe Sejmiki lutowe 1792 roku. Łódź: Wydawnictwo Uniwersytetu Łódzkiego.

Uruszczak, Wacław. 2010. Poselstwo sejmowe w dawnej Polsce. In Drogi i bezdroża nauk historyczno-prawnych, ed. Marian Małecki, 52-56. Bielsko-Biała: Wyższa Szkoła Administracji.

Wachlowski, Zbigniew. 1927. Pojęcie suwerenności w literaturze politycznej polskiej XV i XVI wieku. In Pamiętnik trzydziestolecia pracy naukowej prof. dr. Przemysława Dąbkowskiego wydany staraniem Kółka Historyczno-Prawnego Stuchaczów Uniwersytetu Jana Kazimierza 1897-1927, 221-241. Lwów: skł. gł. Księgarnia Gubrynowicza i Syna.

Walicki, Andrzej. 2000. Idea narodu w polskiej myśli oświeceniowej. Warszawa: Polska Akademia Nauk. Instytut Filozofii i Socjologii.

Willoweit, Dietmar, and Ulrike Seif. 2003. Europäische Verfassungsgeschichte, Rechtshistorische Texte. München: Verlag C.H.Beck.

Żbikowski, Piotr. 1992. Potępienie i obrona ustawy rządowej z 3 maja 1791 roku. Wokół sporu Antoniego Trębickiego z Dyzmą Bończą Tomaszewskim. In Ku reformie państwa i odrodzeniu moralnemu człowieka. Zbiór rozpraw i artykułów poświęconych dwusetnej rocznicy ustanowienia Konstytucji 3 Maja 1791 roku, ed. Piotr Żbikowski, 97-118. Rzeszów: Wydawnictwo Wyższej Szkoły Pedagogicznej.

Zielińska, Zofia. 1986. Ostatnie lata Pierwszej Rzeczypospolitej. Warszawa: Krajowa Agencja Wydawnicza.

Zielińska, Zofia. 1991. „O sukcesyi tronu w Polszcze” 1787-1790. Warszawa: Wydawnictwo Naukowe PWN.

Zienkowska, Krystyna. 1976. Sławetni i urodzeni. Ruch polityczny mieszczaństwa w dobie Sejmu Czteroletniego. Warszawa: Państwowe Wydawnictwo Naukowe. 